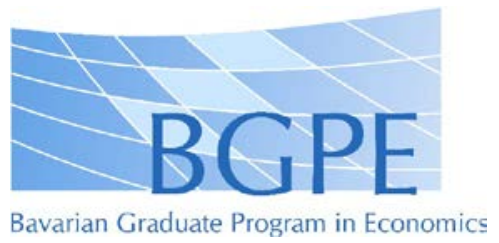

BGPE Discussion Paper

No. 164

\title{
Fertility Effects of Child Benefits
}

\author{
Regina T. Riphahn \\ Frederik Wiynck
}

August 2016

ISSN 1863-5733

Editor: Prof. Regina T. Riphahn, Ph.D.

Friedrich-Alexander-University Erlangen-Nuremberg

(c) Regina T. Riphahn, Frederik Wiynck 


\title{
Fertility Effects of Child Benefits
}

\author{
Regina T. Riphahn \\ (Friedrich-Alexander University Erlangen-Nürnberg) \\ and \\ Frederik Wiynck \\ (Friedrich-Alexander University Erlangen-Nürnberg)
}

August 11, 2016

We exploit the 1996 reform of the German child benefit program to identify the causal effect of heterogeneous child benefits on fertility. While generally the reform increased child benefits, the exact amount of the increase varied substantially by household income and sibship size. We use these heterogeneities to identify their causal effects on fertility in a difference-in-differences setting. We apply the large samples of the German Mikrozensus and the rich data of the German Socio-economic Panel (SOEP). The reform effects on low income couples are not robust or statistically significant. We find some support for positive fertility effects for higher as opposed to lower income couples deciding on a second birth.

JEL Code: J13, I38, C54

Keywords: child benefits, fertility, tax allowance, causal effect, difference-in-differences, Mikrozensus, SOEP

Correspondence to:

Regina T. Riphahn

Friedrich-Alexander University Erlangen-Nürnberg

Lange Gasse 20

90403 Nürnberg, Germany

Phone: +49 - 911 - 5302826

Fax: $\quad+49$ - $911-5302178$

Email: regina.riphahn@fau.de

We gratefully acknowledge helpful comments received at the 2016 CESifo conference on Employment and Social Protection, the BGPE research workshop in Augsburg, the annual ESPE conference in Berlin, and a LASER seminar in Nürnberg. We thank David M. Blau, Kamila Cygan-Rehm, Dominique Lemmermann, Rebecca Schrader, and Caroline Schwientek for helpful comments. 


\section{Introduction}

As many industrialized societies face the problem of demographic aging and low birthrates, it is important to study the determinants of fertility and, in particular, to understand the fertility effects of public policies. In this study, we exploit a major reform of the German child benefit program to investigate whether child benefits affect fertility. As the program combines cash benefits and tax deductions, our analysis is comparable to US studies of fertility effects of personal tax exemptions (e.g., Whittington et al. 1990, Crump et al. 2011). The measures of the German reform varied by household income, which renders it similar to reforms of the EITC (earned income tax credit) in the US and the WFTC (working families tax credit) in the UK. Both programs have been studied for their fertility effects before (see Brewer et al. 2012, Baughman and Dickert-Conlin 2003, or Francesconi and van der Klaauw 2007).

Child benefits - or family cash benefits - are available in many countries, i.e., 30 of 32 OECD countries offer such a program (OECD 2014). In most countries, these benefits are under review and undergo reforms: Australia introduced a flat rate 'baby bonus' in 2004 (Guest and Parr 2013). In the UK, the child benefit was recently withdrawn from higher income households due to fiscal concerns (HM Treasury 2010). France cut back on the 'allocations familiales' in 2015 to reduce expenditures (Reuters 2014). Japan, in contrast, reformed its benefit system in 2010 with the intention to increase fertility (Suzuki 2013). Therefore, the causal effect of child benefits is of broad and international interest.

Up until 1995, Germany organized its family benefit system using income dependent cash transfers plus a system of tax-exempt child allowances. Critics argued that the system disproportionately benefited high-income families. In response, the reform considered here introduced a significant increase in cash benefits and the obligation to choose either the benefit or the tax allowance. We investigate whether this increase in the "financial return to child bearing" affected fertility. 
Germany spends about 33.8 billion Euro annually on child benefits, i.e., more than 10 percent of the federal budget (STBA 2016). By international comparison, child benefits are high and yet Germany remains a low fertility country (BMFSFJ 2008). In this situation, the quasi-experiment induced by the 1996 child benefit reform facilitates an interesting case study on fertility effects; the increase in payments was substantial and affected different population groups in different ways.

This study contributes to a broad international literature, which disagrees on whether benefits affect fertility. While some causal analyses yield strong positive fertility responses to benefit increases, others show small or even negative effects. In the first group of studies, González (2013) evaluates the effect of a one-time payout of 2,500 Euro after a birth in Spain in 2007. Abortions declined and conceptions increased, resulting in an increase of the annual number of births by 6 percent. Cohen et al. (2013) look at changes in the Israeli child subsidy for third and higher order births and confirm significant fertility responses to child subsidy changes particularly in lower income families. Milligan (2005) evaluates the fertility effect of the introduction and modification of tax allowances in Quebec. He also finds substantial fertility increases of up to 25 percent. The effect appears to be largest in high income families. Laroque and Salanié $(2004,2014)$ estimate structural models and simulate fertility effects of benefit increases in France. They find substantial fertility responses but do not differentiate by income.

Conversely, a number of contributions question positive responses of fertility to financial incentives. Crump et al. (2011) revisit the studies by Whittington et al. (1990). Based on richer data and after testing various specifications they reject the hypothesis that child related tax benefits affect the level of fertility. Baughman and Dickert-Conlin (2009) evaluate whether changing incentives in the US EITC program increased fertility, but find the opposite response among white women and no significant effects for non-white women. Francesconi and van der Klaauw (2007) evaluate the UK WFTC program's effect on the fertility of lone mothers. 
Contrary to their hypotheses, they also find negative fertility responses. ${ }^{1}$ Since this reform addressed low income households, heterogeneities by household income cannot be evaluated.

Two surveys summarize the literatures on welfare and family policy effects on fertility: Moffitt (1998) covers the literature on welfare in the US and suggests that the findings on fertility effects are inconclusive. Gauthier (2007) summarizes the international literature on family policy effects on fertility and similarly concludes that the evidence is mixed and with small effects at best.

The German literature on the fertility effects of child benefits entails two relevant yet contradicting contributions: Haan and Wrohlich (2011) estimate a structural, dynamic discrete choice model of joint employment and fertility choices for women in couples. The authors apply monthly data from the 2000-2007 waves of the German Socio-Economic Panel (SOEP) and account for taxes, childcare, child benefits, and out-of-work benefits. They find strong fertility responses to changes in child benefits: a hypothetical increase in child benefits by 20 percent for children under age three is associated with a significant fertility increase by 4.6 percent. The fertility effects are largest among the less educated, those in East Germany, and those without children. Rainer et al. (2012) evaluate the effect of the 1996 child benefit reform using a difference-in-differences approach. The authors use annual observations from the 1992-1998 SOEP waves, i.e., the years surrounding the 1996 child benefit reform. As the reform impact varied by income group, the authors define control and treatment groups based on education as a proxy for income. A positive reform effect appears at best among the low educated with no children; however, the effect is not robust. ${ }^{2}$

It is interesting that the ambiguous empirical findings on the relationship between child benefits and family size go along with indeterminate theoretical predictions. If we consider

1 Brewer et al. (2012) study the same reform and find that the fertility of women in couples indeed increased after the reform.

2 Tamm (2010) studies the same reform with a focus on female labor market participation. Similar to González (2013) he finds that the increase in benefits caused a decline in maternal hours of work. 
children as a "normal good" the income effect of an increase in transfers should be positive and call forth higher fertility. The same positive fertility effect obtains if we interpret child benefit increases as a reduction in the own price of children: it should increase demand, i.e., fertility. If, however, parents consider child quality and child quantity as substitutes (Becker 1991), the fertility effect of an increase in non-labor income depends on whether the income elasticity of child quality exceeds that of child quantity. If that is the case, rising child benefits may even reduce fertility and increase investments in child quality (Ermisch 2003, Gauthier 2007).

The contribution of this study is threefold: first, we add to the international literature by considering the case of Germany as a very low fertility country. As fertility patterns are different here, also fertility responses to financial incentives may contrast to those in the US or the UK. Second, we present detailed analyses of the reform effects on fertility considering heterogeneous incentives by family size. Third, we refine extant analyses of the German reform: in contrast to Rainer et al. (2012) our hypotheses distinguish reform effect on first and second births. We look at evidence from Mikrozensus in addition to SOEP data and thus exploit large samples. Also, we consider strict definitions of control and treatment groups and omit observations where the pre- vs. post-reform assignment is unclear due to potential anticipation of the reform.

Our results confirm the findings of Rainer et al. (2012) in that there are no robust fertility effects of the reform for low income couples. We find, however, some support for positive fertility effects for higher income couples deciding on a second birth at the order of 10 to 23 percent. This finding is in line with our expectations, as the reform increased child benefits for second children particularly for high income families. We provide various robustness tests, which corroborate our findings.

The structure of the paper is as follows: section 2 describes the 1996 child benefit reform and the relevant institutional background; here we derive our two main hypotheses. Section 3 explains our empirical approach to test the fertility effects of the reform. We introduce our data 
from the German Mikrozensus as well as the SOEP in section 4. Section 5 presents our main results, section 6 describes the robustness tests, and section 7 concludes.

\section{Background and Hypotheses}

The German Constitution mandates that families "shall enjoy the special protection of the state" (Article 6). One of the main policy instruments implementing this special protection is a transfer program labelled 'child benefit' (Kindergeld). Since the federal government established it in 1954, it grew continuously in scope and scale. Initially, families only received 25 DM per month for the third child and for children of higher parity. Over time, the transfer was reformed in various ways: the benefits started to be provided additionally to families for second children (1961) and for first children (1975), benefit payout varied by income (1961-1975, 1982-1995), and transfers were raised and at times complemented by allowable income tax deductions for families with children. A decision of the German constitutional court called forth the 1996 reform of child benefits. ${ }^{3}$ The reform resulted in the largest increase in these benefits in Germany ever. The German parliament passed the reform on October 11, 1995, it came into effect on January 1, 1996 and affected all families with children, independent of the date of birth. The reform integrated child benefits and the income tax system: prior to the reform, both systems complemented each other and applied simultaneously (dual system); since the reform, families have to choose between child benefits and tax deductions (option model). It depends on household income whether child benefits or tax deductions are preferable. As our analysis exploits this reform, we now briefly characterize the regulations before and after the reform.

In the years prior to the reform, regulations on child related payments contained three elements. The first element were child benefits, which amounted to $70 \mathrm{DM}$ per month for the first child and varied by family income for higher order children (70-130 DM for a second child,

3 This decision was taken in 1990 and stipulated that amounts covering the basic needs of parents and their children must be exempted from income tax. 
70-220 DM for a third child, and 70-240 DM for fourth and higher order children). Table 1 summarizes the child benefit amounts transferred for children of different parity over time. The second element were income tax exempt amounts of 4,104 DM to be deducted from parental taxable income per child and year. Due to the progressive income tax system, this saved parents between 0 and $181 \mathrm{DM}$ per child and month; the amount increased with income. ${ }^{4}$ The third element were supplementary payments; they amounted to between 1 and 65 DM per child and month, decreasing with income. They were intended to mitigate the relative advantage the tax exemptions granted to high income families. Overall, every family received at least $135 \mathrm{DM}$ per child and month, based on a combination of the three elements (Rainer et al. 2012).

After the 1996 reform, the supplementary payments were abolished and child benefit payments no longer varied by income. The benefits amounted to $200 \mathrm{DM}$ for the first and second child, $300 \mathrm{DM}$ for the third child, and $350 \mathrm{DM}$ for the fourth child and any further children. ${ }^{5}$ Furthermore, the reform increased the tax exempt amounts to 6,264 DM (see Lüdeke and Werding 1996). While parents could receive tax advantages plus child benefits prior to the reform, after the reform only one of the two could be realized: families with low income benefited more from the child benefit payments whereas the tax exempt amounts per child were the more attractive option for higher income households due to progressive tax rates. ${ }^{6}$

While the reform generally increased the net value of child-related transfers for almost all families, the magnitude of the increase varied across the income distribution and the number of children. Figure 1.1 depicts the total value of net child related transfers (i.e., child benefits,

\footnotetext{
$4 \quad$ Families with an annual income below 11,232 DM saved nothing, because they did not pay any income taxes. Families with an annual income above 244,188 DM paid the maximum tax rate of 53 percent and thus saved 4,104 $\mathrm{DM}^{*} 0.53 / 12=181 \mathrm{DM}$ per month and child.

The benefits rose even further in 1997 and again in 1999. By 1999 they had reached 250 DM for the first and second, 300 and 350 for the third and fourth child, respectively.

6 It was not the family but the tax authority, which automatically chose the financially more attractive option for each individual family. Generally, gross family annual income for couples without children had to surpass about 146,500 DM after the reform to make the tax exempt amounts more attractive (about 153,000 DM for couples with one child). Based on our data, fewer than five percent of couple and family households were in this top income bracket. Therefore, the vast majority of families benefited from child benefits rather than the tax credit.
} 
child benefit supplement, savings through tax deductions) before and after the reform for a first child. The gross income on the x-axis refers to the household income of married couples with no children. ${ }^{7}$ The graph describes the reform-induced change in financial incentives for couples considering to have a first child.

The reform increased the net value of child related transfers almost across the entire income distribution. The only exception were couples with annual incomes between 143,400 and 152,500 DM, for whom net transfers decline slightly. ${ }^{8}$ Couples with incomes above this interval benefited from the increased tax exempt amounts, couples with incomes below this interval benefited from the increased direct transfers. Clearly, the largest absolute increase in net transfers occurred for low income couples: for couples with an income below 23,232 DM child benefits increased from 1,650 to 2,400 DM per year, i.e., by 45.45 percent.

Figure 1.2 shows net transfers relative to yearly gross family income. At a gross income of, e.g., 20,000 DM the reform increased potential transfers from 8.15 to 12.0 percent of income. With rising income, the increase in relative net transfers declines.

If children are a "normal good", the increase in net transfers should raise fertility. The effect should be largest for those with the largest increase in benefits. Net transfers for firstborn children increased the most for low-income families, both in absolute and relative terms. This leads us to our first hypothesis:

We expect a positive fertility response to the reform among previously childless couples. We expect this positive response to be larger for low-income than for high-income couples.

Figure 2.1 presents the absolute net transfers which couples who already have one child could expect from a second born child before and after the reform. For second children, the reform implied different shifts in incentives: after the reform, families with an annual income

$7 \quad$ As tax and child benefit laws differentiate between married and unmarried couples, the patterns for unmarried couples are slightly different.

$8 \quad$ Net transfers dropped by between $9.50 \mathrm{DM}$ and $18.85 \mathrm{DM}$ per year, i.e., negligible amounts. 
of up to $32,000 \mathrm{DM}$ gain only slightly (up to $60 \mathrm{DM}$ per year). Families with an income between 32,000 and 62,500 DM lose up to $190 \mathrm{DM}$ per year in terms of net transfers for a second child. Couples with an income above the threshold of $62,500 \mathrm{DM}$ were subject to discretionary income related reductions in child benefits before the reform. They gain because the reform abolished these reductions. The increase in net transfers amounts to up to $520 \mathrm{DM}$ per year.

Figure 2.2 depicts the net transfers due to a second child relative to household income. In the lower part of the income distribution net transfers declined with the largest drop at an income level just below the threshold of $62,500 \mathrm{DM}$ (i.e., at $62,400 \mathrm{DM}$ ), where it dropped from 4.5 percent in 1995 to 3.85 percent in 1996. The largest relative increase in net transfers occurred slightly above the threshold at 63,800 DM, in particular from 2.94 percent of gross income in 1995 to 3.76 percent in 1996.

Overall, the reform reduced net transfers for second born children as a share of household income for low-income families and increased them for high-income families. Note that overall these families' disposable income increased after the reform as the increasing benefits for first born children overcompensate benefit reductions for second births (for a depiction see Figure A.1 in the appendix). This leads to our second hypothesis:

We expect an overall positive fertility response to the reform in terms of second born children. We expect this positive response to be larger for high-income than for low-income families.

Figure 3 shows the net transfers for a third child, from the perspective of a couple with two previous children. Net transfers increased for most families, but they did not rise monotonously with household income. Furthermore, for families with an income between about 55,400 and 80,900 DM the income related fertility incentive declined after the reform. Here, we cannot derive clear income based hypotheses about differential fertility responses for highvs. low-income families. The situation is even more complicated for children of fourth and fifth 
parity. Therefore, we limit our analyses to the reform's fertility effect on first and second births. Appendix B studies the situation for third births.

Four additional institutional features and changes are relevant for our analyses (see Rainer et al. 2012): first, the number of years for which parents could claim child benefits increased in 1996 from 16 to 18 years. ${ }^{9}$ If the child benefit reform yields heterogeneous fertility effects, then extending the payout period magnifies these differences across income groups. Second, child benefits are considered in the means test for social assistance: when child benefits increase, welfare payments decline by the same amount. Therefore, the reform does not affect the fertility incentives of welfare recipients and we exclude them from our analyses. ${ }^{10}$ Third, on January 1, 1996 a reform became effective that introduced a legal entitlement for a place in a half-day kindergarten for three year olds. As this reform had been passed already in 1992 (Kinder- und Jugendhilfegesetz 1992) we do not expect to see specific fertility responses to this reform at the cutoff date of the child benefit reform in 1996. Fourth, a general income tax reform took effect along with the child benefit reform starting January 1, 1996. This reform decreased the tax burden, mostly for low-income earners. ${ }^{11}$ - In the next section, we describe our empirical strategy and explain how our strategy responds to the reforms in childcare and the income tax system which occurred simultaneously with the child benefit reform.

\section{Empirical Strategy and Identification}

\subsection{Empirical Strategy}

Our strategy to identify the causal fertility effect of the child benefit reform rests on the heterogeneity of the reform's effect for low- and high-income families. We use this heterogeneity and apply a difference-in-differences approach.

\footnotetext{
9 If children are in training parents can receive benefits up until age 25.

10 In principle, welfare recipients constitute an independent control group for the reform. However, as our data provide very few births in this subsample (56 overall), we only pursue this strategy as a robustness check.

11 In appendix Figure A.2 we show the reform induced shift in marginal and average tax rates.
} 
Following Becker (1991), we assume that the cost of a marginal child affects parents' desired number of children. Overall, we expect a positive fertility response to the reform, because child benefits increased for virtually every family. Regarding first (second) births, financial incentives increased most for low-income (high-income) families such that we expect a stronger response of that group. We analyze reform effects separately for families without previous children and for families with one previous child.

As income is likely to be endogenous to fertility, we cannot use it to define treatment and control groups. Instead and in order to proxy for income, we follow the literature (e.g., Brewer et al. 2012) and use parents' education, which is arguably more exogenous to fertility. Couples with low vs. high educational attainment make up the treatment vs. control groups in the sample of childless couples. For the sample of couples with one child, we reverse the definition of treatment and control group, because in this case the high-income or highly educated couples experienced the largest increase in net transfers. To isolate the treatment effect $\gamma$, we estimate a linear model of the form:

$$
y_{i t}=\alpha \text { treat }_{i t}+\beta \text { post }_{i t}+\gamma(\text { treat } \cdot \text { post })_{i t}+x_{i t}^{\prime} \delta+\varepsilon_{i t} .
$$

The dependent variable $y$ indicates whether couple $i$ in period $t$ had a birth in the previous 12 months. The variable treat denotes whether a couple belongs to the treatment group. The variable post yields whether the fertility decision occurred after the reform. The covariate vector $x$ describes, e.g., characteristics of both parents. The coefficient of the interaction between treat and post $(\gamma)$ captures the treatment effect which we estimate by ordinary least squares regressions.

\subsection{Identification Issues}

In this section, we discuss four relevant challenges to our identification strategy: first, fertility responses in anticipation of the reform, second, the childcare reform, third, the income tax reform and fourth, the existence of parallel trends between low- and high-educated couples. 
The first challenge is that couples may have anticipated the reform. If they adjusted their fertility already prior to the implementation of the reform on January 1, 1996, this might bias the estimated reform effect. The German parliament passed the reform in October 1995 (Bundeskindergeldgesetz 1995). Thus, children conceived in (immediate) response to the new law could not have been born prior to June 1996 . We carefully separate pre- and post-reform fertility outcomes and take account of an intermediate anticipation period. ${ }^{12}$

The second challenge to our identification strategy is the introduction of an entitlement to subsidized half-day childcare for children aged three and above. If this reform affected the fertility of our treatment and control groups differentially, our estimates might conflate the effects of the two reforms. This, however, is unlikely: while both reforms came into effect the same day, the German parliament passed the law introducing the childcare entitlement as early as summer of 1992 (Kinder- und Jugendhilfegesetz 1992). Therefore, fertility responses to this reform may have been realized already in the three years leading up to the enactment of the childcare reform. In addition, if the reform of childcare entitlements swayed any parents to have a child, the resulting children would have led to increased kindergarten enrollments of three year olds once the childcare reform was in effect. As enrollment of three year olds stayed stable in the years after the enactment of the reform (BMFSFJ 2005), we argue that the childcare reform does not cause fertility responses as of 1996 and therefore does not threaten our identification approach.

The third challenge to our identification strategy is the income tax reform which parliament passed together with the child benefit reform. The income tax reform increased the

\footnotetext{
12 However, the Bundestag first discussed the reform in March 1995 and its specifics were under debate until October. If (potential) parents adjusted their fertility choices already in anticipation and conceived a child as early as April 1995, births as early as January 1996 may already be in response to the reform. This is an unlikely outcome: first, it is uncommon that pregnancies occur immediately and, second, it would be surprising to see parents respond already to the possibility of a reform. However, in the unlikely event that parents responded to the reform very early, we were to underestimate the true reform effect because we would overestimate pre-reform fertility.
} 
disposable income of low-income families while high-income families were hardly affected (see Figure A.2 and Lüdeke and Werding 1996). Thus, we expect that the income tax reform has a positive fertility effect which decreases with income.

As our identification strategy does not allow us to control for this effect, we obtain an upward bias in our estimate of the treatment effect for childless couples. However, the estimation of a significantly positive treatment effect would show that the fertility of the lowincome group responds to changes in net income. The largest reduction of the tax burden from the income tax reform applied to couples with a taxable income of 24,100 DM. Their tax reductions amounted to about 2,500 DM while the increase in potential benefits from a first child amounted to $780 \mathrm{DM}$. Thus, 23.8 percent of the potential total income increase is conditional on having a first child. Therefore, at least about one quarter of any estimated effect is connected to the increase in child benefits.

The situation is reverse for the analysis of second births: here, the fertility response to the child benefit reform among high-income families should exceed that of low-income families. A fertility effect of the general tax reduction for low-income families with a first child would downward bias the estimated differential effect of the child benefit reform on second births. Therefore, difference-in-differences estimates constitute a conservative lower bound.

The fourth challenge to our identification strategy is to show that fertility for treatment and control groups developed along parallel paths in the periods prior to the reform (common trends assumption). As aggregate fertility rates are not available by parental education and child parity, we use the information provided in the large Mikrozensus surveys of 1995 and 1999 to approximate the different birthrates over the relevant period. ${ }^{13}$ The calculation of past birthrates is based on the age distribution of children observed at the time of the interview. Based on the observed children in the household, we impute a couples' past fertility. We proxy past birthrates

13 Exact data are available in the SOEP, as well. However, the small number of observations in the relevant groups does not permit informative depictions of the developments; the resulting figures jump erratically. 
by relating the number of couples with a birth to those without one. In this approximation, we consider only married couples, because for them we know the date of marriage and thus the duration of the partnership. Clearly, the approach is imprecise as, e.g., couples with births in the past may have split, children may not be living in a couple's household, and unmarried couples are not considered altogether. Figures 4.1-4.4 describe the development of birthrates for married couples in the treatment and control groups, i.e., with high and low education. We show first the development for previously childless couples and then for couples with one previous child. We offer two definitions of education groups (narrow and broad) which we define in the next section. The figures yield parallel developments of pre-reform birthrates, which suggests that the common trends assumption holds.

\section{$4 \quad$ Data}

\subsection{Mikrozensus}

Our first data source is the German Mikrozensus which samples one percent of German households. We use the 1995-1999 waves of data. The interviews took place in April of each year. The scientific use files provide access to 70 percent of the overall sample.

We consider married and non-married cohabiting couples where the woman is at least 25 years old, i.e., at an age when most individuals have finished their education. ${ }^{14} \mathrm{We}$ set the upper age limit for women in the sample to 40 years because fertility rates of older women are very small (for similar strategies see Rainer et al. 2012 and Brewer et al. 2012). We only consider West Germany because East Germany exhibited very unstable fertility patterns in our observation period, right after unification (Goldstein and Kreyenfeld 2011). We use couples

14 We do not study the behavior of single women because their fertility rates are very low $(1.25$ percent among childless and 1.0 percent among those with one child compared to about 10 percent among couples) and because their economic situation of single mothers is governed by different mechanisms: it is affected by the scarcity of child care supply for infants in the 1990s and social norms that pushed recent mothers out of the labor market. About one third of single mothers receive welfare benefits. We expect that the single mothers respond less to child benefit reforms than couples. The issue is left for further research. 
where both partners are German nationals to limit the impact of heterogeneous fertility cultures (Cygan-Rehm 2014). We exclude welfare recipients because the reform did not change this group's income situation (Bundessozialhilfegesetz 1991).

The dependent variable describes whether the couple has a child under the age of one living in the household. ${ }^{15}$ We consider the observations from the Mikrozensus waves 1995 and 1996 as the pre-reform sample. As the interviews took place in April, newly born children below age one observed in these surveys must have been conceived by July 1995 before the reform law was passed. We observe post-reform fertility outcomes based on the Mikrozensus waves 1998 and 1999. Again, we consider children below age one in the household. The earliest possible date of conception for below one year olds observed in April 1998 is July 1996 and therefore well after the reform came into effect. Our sample thus covers births from April 1994 to April 1996 as pre- and from April 1998 to April 1999 as post-reform outcomes. We omit births between April 1996 and April 1997 because without information on the month of birth we cannot determine whether they were conceived before or after the reform (uncertainty gap).

We use educational attainment of both partners based on the International Standard Classification of Education scale of 1997 (ISCED) to proxy the low- and high-income groups which make up our treatment and control groups. ${ }^{16}$ We apply two definitions of low vs. high education in our regressions: a narrow definition offers a precise approximation of the relevant income groups and a broad definition maintains larger sample sizes.

The narrow definition labels all couples where both partners have at most ISCED-level 2 as low education and all couples where both partners have ISCED-level 4 or higher as high education couples. Here, the highly educated couples clearly have higher incomes than the

15 The Mikrozensus provides the age of all members of the surveyed households. If there is a child of age 0 living in the household, we consider this to be a recent birth.

16 In a robustness test we consider fathers' education only, in order to avoid the potential endogeneity of maternal education with respect to fertility choices. Table A.1 in the appendix describes the ISCED coding in terms of school and vocational degrees. We present the distribution of annual household net income and the income-specific birthrates in Figure A.3 in the appendix. 
lowly educated: Figure 5.1 shows the income distribution of both groups in the narrow definition for couples without children. Figure 5.2 shows the same for couples with one previous child; the dashed line represents the turning point in terms of increasing or decreasing incentives for a second child in terms of net incomes based on the child benefit regulations (see Figure 2.2). ${ }^{17} 55.2$ percent of the low education couples have an income below this threshold and 82.3 percent of the high education couples have an income above the threshold.

The broad definition of low and high education labels couples where both partners reach at most ISCED-level 3 as low education and couples where at least one partner reaches ISCEDlevel 4 or higher as high education couples. The advantage of this definition is that all observations can be assigned to a group. The disadvantage is that the incomes of the groups are less distinct than in the narrow definition. Figures $\mathbf{5 . 3}$ and $\mathbf{5 . 4}$ show the income distributions for low and high educated couples in the broad definition without children and for couples with one child, respectively.

Table 2.1 provides the sample sizes and birthrates for both definitions and for couples without children and with one child. We can apply analysis samples of $11,385(7,046)$ observations in the narrow education definition and of $36,304(33,175)$ in the broad definition for couples at risk of a first (second) birth, respectively. Births of firstborn children declined after the reform and did so more strongly for the lowly educated. Births of second born children increased for all groups except the lowly educated in the narrow definition.

Our estimations consider a vector of control variables. These capture parents' age and marital status and (for families with a previous child) years since last birth. We lag these variables to the year prior to the birth in order to capture parents' characteristics at the time of conception. Furthermore, we control for the survey year, the federal state and the size of the

17 This threshold lies at annual gross household incomes of roughly 63,000 DM. Since we only have data on net income in the Mikrozensus, we provide the income distribution in terms of net income, for which the threshold is roughly at 43,000 DM. 
community the couple lives in. We show descriptive statistics on the covariates in Tables A.2 and A.3.

\subsection{German Socio-economic Panel (SOEP)}

Our second data source is the German Socio-economic Panel, a long running household survey (Wagner et al. 1997). The SOEP provides smaller samples than the Mikrozensus, but offers full fertility biographies. We use the 1992-1998 survey waves of the SOEP and generate a data set which is comparable to that based on the Mikrozensus.

Again, we consider cohabiting couples in West Germany. We exclude couples if one of the partners has a migration background. ${ }^{18}$ We drop welfare recipients and couples where the female is outside the age range of $25-40$ years. This provides us with an analysis samples of 314 (262) observations in the narrow education definition and of $1,224(1,414)$ in the broad definition for couples at risk of a first (second) birth, respectively.

Again, our dependent variable describes couples' fertility outcomes. While in the Mikrozensus we observe whether there is a child in the household and impute parental characteristics at the time of conception, the SOEP allows us to connect observations on families over time. We combine a couple's characteristics in the year of the interview with their fertility outcomes in the following calendar year.

Given that the reform was first discussed in March 1995 and the law passed parliament in October 1995 to take effect January 1, 1996, conceptions between March and October 1995 (i.e., births between about December 1995 and June 1996) fall into a transition period (uncertainty gap). In order to assign fertility outcomes correctly to the pre- vs. post-reform period we do not use the 1995 interviews and 1996 fertility outcomes. We depict our sampling

18 In the Mikrozensus data we dropped non-nationals because there is no information on the preferable indicator of migration background. 
strategy with respect to the assignment of pre- and post-reform outcomes and the connection between couples' characteristics and fertility for the Mikrozensus and SOEP data in Figure A.4.

As before, we define treatment and control groups based on the ISCED education scale.

Table 2.2 provides sample sizes and birthrates pre- and post-reform for the two different definitions of high and low education. Again, our covariates include parents' age, federal state, and marital status and (for families with a previous child) categorical indicators of birth spacing. Also, we control for the month and year of the interview. Tables A.4 and A.5 show descriptive statistics of all covariates, except for years and interview months.

\section{Results}

Tables 3-6 show the estimation results of our difference-in-differences models. Tables 3 and 4 show results for first and second births based on the Mikrozensus and Tables $\mathbf{5}$ and $\mathbf{6}$ those for first and second births based on the SOEP data. In each table, we describe the findings based on the narrow definition of treatment and control group in columns 1 and 2 and based on the broad definition in columns 3 and 4 .

Table 3 presents the estimation results for couples with no previous children. In columns 1 and 2 the coefficients show virtually no change in fertility for the reference group of high educated couples in the post-reform period, and a generally lower fertility for low compared to high educated couples. Our main interest rests on the coefficient of the interaction of low education and post-reform indicators, i.e., the causal effect of the higher child benefit increase for low income families. Contrary to our expectation of a positive treatment effect, the coefficient is negative and statistically significant in columns 1 and 2, i.e., with and without additional controls.

We can offer two explanations for this surprising result: first, if low educated couples have lower ages at first birth our sample which conditions on the female being at least age 25 may overlook some births in the treatment group. When we add younger females to the sample 
the negative effect loses statistical significance (results available upon request). A second explanation may be that the treatment group contains a share of couples who had migrated from East to West Germany. As East Germans experienced vast fertility declines after reunification (total fertility rates dropped from 1.57 in 1989 to 0.77 in 1994, see Conrad et al. 1996) this might drive the negative effects. Unfortunately, the Mikrozensus data do not offer information on individual migration histories.

In columns 3 and 4 of Table 3, again, the coefficient of the interaction term again does not yield the expected positive fertility effect for the lower income couples after the reform. It is small and statistically insignificant. Thus, the Mikrozensus data yield no evidence to support our first hypothesis.

Table 4 presents the Mikrozensus based estimation results for reform effects on the propensity of a second birth. In columns 1 and 2, the estimated coefficient of the post- reform indicator is negative and statistically significant. The estimated treatment effect is positive and statistically significant. This indicates a general fertility reduction after the reform which the reform mitigated for the highly educated. The size of the treatment effect appears plausible: after the reform, the fertility of highly educated couples with one child remains fairly stable, while that of low educated couples with one child drops by 4.5 percentage points (see column 2) yielding a positive post-reform effect of 22.6 percent. ${ }^{19}$ The estimations for the broad definition of control and treatment groups yield smaller coefficient estimates: however, when control variables are considered, the coefficient of the interaction term again is statistically significant and positive suggesting a 9.6 percent difference in the fertility increase for the treatment group compared to the control group. ${ }^{20}$ Overall, the results based on the Mikrozensus data agree with our second hypothesis.

1922.6 percent are obtained when dividing the estimate of the reform effect $(0.037)$ by the prereform birth rate for highly educated couples in the narrow definition (0.164), see Table 2.1.

209.6 percent are obtained when dividing the estimate of the reform effect $(0.013)$ by the prereform birth rate for highly educated couples in the broad definition (0.135), see Table 2.1. 
Tables 5 and 6 show the results based on the SOEP data. Here, sample sizes are reduced by more than factor twenty compared to the Mikrozensus data. The main effects of the reform on the probability of having a first birth (row one in Table 5) confirm the results from the Mikrozensus: there is no support for the hypothesis that the reform yielded a significant general fertility effect. Again, lower educated couples tend to have fewer first births than higher educated couples. However, we find no support for hypothesis one as the estimated coefficients for the interaction terms are statistically insignificant. Table 6 shows the results of SOEP based tests of hypothesis two. While the propensity to have a second child increased after the reform we find no evidence that the reform yielded a significant positive fertility effect for the high vs. low educated couples with one previous child. All estimated treatment effects in Table 6 are negative. The estimations based on SOEP data confirm the findings of Rainer et al. (2012) who find no robust reform effects using this data source.

Overall, we obtain no support for hypothesis one and some support for hypothesis two based on the Mikrozensus samples. Next, we discuss a set of robustness tests for these findings.

\section{Robustness Tests}

We performed numerous robustness tests and discuss five sets of additional results:

First, Table 7 presents the estimation results when we replace the education proxies by measures of household income. These results may be inconsistent if the endogeneity of income generates, e.g., an upward bias in the fertility-income gradient. Nevertheless, the estimates of the reform effects may still yield the correct sign. We contrast couples in the lowest income quartile with those in the highest quartile. In the first two columns, we consider only couples without prior children; here, the low income couples are the treatment group. In columns 3 and 4, we only consider couples with one prior child. Here, the high income couples are the treatment group. The results display no general rise in fertility after the reform and a negative correlation of income with fertility. None of the four models yields statistically significant 
treatment effects, i.e., the estimates of all 'income by post-reform' interactions are statistically insignificant. This confirms that the reform most likely did not yield substantial fertility effects. Performing the same analysis with data taken from the SOEP similarly yields no statistically significant estimates of treatment effects (see Table A.6 in the appendix).

In addition to grouping high and low income households based on belonging to the first or fourth quartile of the household income distribution, we split the sample based on the income cutoff that separated the households with one child into those that lost or hardly gained by the reform and those that gained substantially (cf. Figure 2.1). That value amounts to gross household incomes of 63.000 DM per year. As the Mikrozensus only provides net household incomes, we approximated the gross income cutoff using a net income cutoff of $43.000 \mathrm{DM}$. Table A.7 shows the estimation results based on the Mikrozensus data, Table A.8 shows the results based on the SOEP, where we can apply the gross income cutoff. The estimates in Table A.7 confirm those in Tables 4 and 7 and show a positive and in the specification without control variables significant treatment effect on second births at the order of about 9 percent. The SOEP estimates for the treatment effect on first births are negative and significant with and without controls. This supports the findings from Table 5. The coefficients for the effect on second births are statistically insignificant. ${ }^{21}$

A second robustness test focuses on our sample selection. We originally omitted couples from East Germany, immigrants, and those with females younger than 25 or older than 40. In Tables 8 and 9 we present the results of estimations based on Mikrozensus data for first and second births when these sample restrictions are lifted. ${ }^{22}$ The results for couples without prior children (Table 8) confirm the previous findings using the main sample: the treatment effect is

21 In addition, we replaced the education proxies that are based on both spouses' education outcomes by focusing on the male spouses' education exclusively, as that may be more exogenous than female education. The results are robust to this modification.

22 We also generated the estimation results when each of the limitations was restricted individually. The results are very similar. 
negative and statistically significant for the narrow definition and small and insignificant for the broad definition of treatment and control group.

Table 9 presents the estimates for the reform effect on second births. Columns 1 and 2 yield the expected positive effect for high education couples, but the effect is statistically insignificant and its magnitude is smaller than in the main regressions in Table 4. The estimated reform effects in columns 3 and 4 are comparable in size to those in the main regressions and statistically significant, thus corroborating prior results. Thus, we continue to find evidence in favor of a positive reform effect on second births. Overall, our results are robust against changes in the selection of the analysis sample. ${ }^{23}$

In addition, we tested whether our results hold up when we only consider married couples. The estimation results based on the thus reduced samples are very close to the results obtained in Tables $\mathbf{3}$ and $\mathbf{4}$ with significantly positive effects for second births (see Tables A.9 and $\mathbf{A . 1 0}$ in the appendix).

In a third set of robustness tests, we compare reform effects for couples with and without welfare receipt. ${ }^{24}$ This is of interest as couples who received welfare were unaffected by the reform: any child benefit increase was deducted from their welfare payments and net transfers remained constant. In Table 10, we study the response of parents without prior children. Here, we expect a positive treatment effect in the low education group. In columns 1 and 2 of Table 10, we only consider low educated households based on the narrow definition and compare the welfare recipients among them who are newly added to the sample, to non-recipients. In row 2 we observe that compared to low educated welfare recipients the low educated non-recipients generally have a significantly higher propensity to have a first birth. Contrary to our

23 We also considered the SOEP data with the extended sample definition in robustness tests. Again, the estimates of the treatment effects remain insignificant both for first and second births.

${ }_{24}$ This comparison is not plausible for couples with one child where we expect the positive treatment effect among those with high income. As high education and high income couples are not likely to be on (means-tested) welfare, we do not use the control group of welfare recipients to test our second hypothesis. 
expectation, the estimated treatment effect in row 3 is negative, statistically significant, and quite substantial. However, these results are based on a rather small sample which comprises only 99 welfare recipients and with only a single birth among them over the entire period of observation.

In columns 3 and 4 of Table 10 we repeat this analysis using the broad definition of couples' educational attainment. In this case, the overall sample size increases by factor ten and we observe 232 welfare recipients with 13 births. Here, we do not find a significant treatment effect. In columns 5 and 6 of Table 10, we consider all couples without children without conditioning on education. We expect that overall the reform increased incentives for additional births among non-recipients, while welfare recipients' fertility remained unaffected. However, again all coefficient estimates of interest are statistically insignificant which suggests that those affected by the reform do not modify their fertility compared to those not affected.

In our fourth set of robustness tests we study state level heterogeneities that may affect responses to federal reforms. In particular, one might expect different fertility responses in states with high and low child care supply or with high and low aggregate unemployment. So far, all our models already controlled for federal state fixed effects. Now, we considered specifications which add state-level linear and quadratic time trends. The main findings are robust to the additional controls. Table A.11 shows the results.

Our final set of robustness tests considers the timing and spacing of births. As we find some evidence for positive fertility effects on second births for high income households, it is of interest whether this truly increases fertility. Alternatively, the positive effect might be due to timing, i.e., an earlier second birth in the mothers' life, or to spacing, i.e., reduced birth intervals between first and second births. As these analyses use only the small subsample of mothers who gave birth in the period of observation, we neglect the very small SOEP samples and focus instead on results from the Mikrozensus. In Table A.12, we present the estimation results when the dependent variable is the age of mothers who gave a second birth. If the fertility effect were 
due to an earlier timing of birth, we would expect a significant negative effect of the reform. However, we find the opposite: after the reform, higher educated mothers were older than before the reform. In order to investigate whether spacing matters, Table A.13 shows estimation results where the dependent variable reflects the time between the first and the second birth. If the fertility increase were due to reduced birth intervals, we would expect a negative reform effect. However, none of the coefficient estimates is statistically significant. Therefore, it is unlikely that the fertility effect is due to timing or spacing. ${ }^{25}$

\section{Conclusions}

In this paper, we apply a difference-in-differences approach to identify the causal effect of an increase in child benefits on fertility in Germany. We use the heterogeneity of the reform across population groups to identify treatment and control groups and to differentiate couples who are more and less strongly affected by the reform. From a theoretical perspective, an increase in child benefits can be expected to yield positive fertility responses. Particularly for low income parents deciding on a first birth and for high income parents deciding on a second birth increased transfers reduced the cost of additional children.

We apply data from the German Mikrozensus and the German Socio-economic Panel (SOEP) and approximate treatment and control groups based on educational attainment. We do not find a positive treatment effect for low income couples deciding on a first child. We find some evidence of a positive fertility effect for higher as opposed to lower income couples deciding on a second child of between 9.6 and 22.6 percent when we use the Mikrozensus data. Numerous robustness tests confirm these findings. The increasing responsiveness of fertility

\footnotetext{
25 We also estimated the timing effect for first births. Based on the Mikrozensus data we obtain significant negative effects of the reform on maternal age at first birth, which were highly significant with the narrow definition of education and statistically insignificant and smaller with the broad definition. This suggests that the lack of a positive fertility effect for first births is not due to a postponement of births. If the reform brought about a reduced age at motherhood, it is possible that the lack of a short-run positive fertility effect for first births will be accompanied by a long-run increase in completed fertility.
} 
across child parity agrees with the observation that the marginal cost of an additional child may be declining in family size. Milligan (2005) found for a reform in Quebec that the response to financial fertility incentives increase with family size. Our results are in line with these findings.

However, in contrast to some of the literature, our analysis does not yield evidence of a general fertility incentive provided by child benefit payments which starts already with first births. This is notable as the nominal benefit amount changed substantially from 70 to $200 \mathrm{DM}$ already for first births. In principle, the difference of the reform impact for treatment and control groups might be insufficient to identify an effect. We can rule out that mismeasurement connected to using income proxies drives the lack of a general effect: when we define treatment and control groups based on income we do not find significant correlation patterns, either. Also, for two reasons it seems unlikely that the lack of a strong fertility effect is driven by a child quality-quantity tradeoff where additional income could be invested in the quality rather the quantity of children: first, this tradeoff should not be relevant for decisions on first births. Second, we do find evidence supporting an increase of second birth fertility where the tradeoff in favor of quality instead of quantity should matter.

While some of the literature which finds positive and significant fertility effects of transfers uses fully parametrized structural models (e.g., Laroque and Salanié $(2004,2014)$ and Haan and Wrohlich (2011)), we identify the causal effect of benefits based on a quasi-natural experiment. Also, many prior contributions evaluated the fertility response to benefit increases just for low income households (e.g., Brewer et al. 2012, Francesconi and van der Klaauw 2007, Baughman and Dickert-Conlin 2009), or only for third and higher order births (Cohen et al. 2013). In contrast, we consider a universal child benefit. Our results are in line with Milligan (2005) who finds no fertility effects of general benefit increases in the low income population, but positive significant effects for high income households.

Overall, not finding strong fertility effects is an important result for family policy, which often relies on cash transfers to secure the financial wellbeing of young families and to 
incentivize childbearing. Given the substantial resources invested in child and family support, e.g., in the case of Germany, it is important to know that they are not likely to be effective in incentivizing first births and that they are particularly ineffective for low income couples. 


\section{Bibliography}

Baughman, Reagan and Stacy Dickert-Conlin, 2003, Did Expanding the EITC Promote Motherhood? American Economic Review 93(2), 247-251.

Baughman, Reagan and Stacy Dickert-Conlin, 2009, The earned income tax credit and fertility, Journal of Population Economics 22(3), 537-563.

Becker, Gary S., 1991, A treatise on the family. Enlarged edition, Harvard University Press, Cambridge.

BMFSFJ (Bundesministerium für Familie, Senioren, Frauen und Jugend), 2005, Zwölfter Kinder- und Jugendbericht, Publikationsversand der Bundesregierung, Rostock.

BMFSFJ (Bundesministerium für Familien, Senioren, Frauen und Jugend), 2008, Dossier: Kindergeld in Deutschland - Familien wirksam fördern, Berlin.

BMF (Bundesministerium für Finanzen), 2008, Datensammlung der Steuerpolitik 2007, edition of July 2008, Berlin.

Brewer, Mike, Anita Ratcliffe, and Sarah Smith, 2012, Does welfare reform affect fertility? Evidence from the UK, Journal of Population Economics 25(1), 245-266.

Bundeskindergeldgesetz 1995, edition of October $11^{\text {th }}$, 1995. In: Bundesgesetzblatt Jahrgang 1995 Teil I, S. 1378.

Bundessozialhilfegesetz 1991, edition of January 10th, 1991. In: Bundesgesetzblatt Jahrgang 1991 Teil I, S. 105, § 77 (1).

Cohen, Alma, Rajeev Dehejia, and Dmitri Romanov, 2013, Financial Incentives and Fertility, Review of Economis and Statistics 95(1), 1-20.

Conrad, Christoph, Michael Lechner, and Welf Werner, 2016, East German fertility after unification: crisis or adaptation? Population and Development Review 22(2), 331-358.

Crump, Richard, Gopi Shah Goda, and Kevin J. Mumford, 2011, Fertility and the Personal Exemption: Comment, American Economic Review 101(6), 1616-1628.

Cygan-Rehm, Kamila, 2014, Immigrant Fertility in Germany: The Role of Culture, Schmollers Jahrbuch - Journal of Applied Science Studies 134(3), 305-340.

Ermisch, John F., 2003, An Economic Analysis of the Family, Princeton University Press: Princeton, New Jersey.

Francesconi, Marco and Wilbert van der Klaauw, 2007, The Socioeconomic Consequences of "In-Work" Benefit Reform for British Lone Mothers, Journal of Human Resources 42(1), 1-31.

Gauthier, Anne H., 2007, The impact of family policy on fertility in industrialized countries: a review of the literature, Population Research and Policy Review 26(3), 323-346.

Goldstein, Joshua R. and Michaela Kreyenfeld, 2011, Has East Germany Overtaken West Germany? Recent Trends in Order-Specific Fertility, Population and Development Review 37(3), 453-472.

González, Libertad, 2013, The effect of a universal child benefit on conceptions, abortions, and early maternal labor supply, American Economic Journal: Economic Policy 5(3), 160 188.

Guest, Ross and Nick Parr, 2013, Family Policy and couples' labour supply: an empirical assessment, Journal of Population Economics 26(4), 1631-1660.

Haan, Peter and Katharina Wrohlich, 2011, Can child care policy encourage employment and fertility? Evidence from a structural model, Labour Economics 18(4), 498-512.

HM Treasury, 2010, Press Release Oct.,4 2010: Chancellor announces reforms to the welfare system, https://www.gov.uk/government/news/chancellor-announces-reforms-to-the-welfaresystem [last access 2016-May-23].

Kinder- und Jugendhilfegesetz, 1992, edition of July 27th, 1992. In: Bundesgesetzblatt Jahrgang 1992 Teil I, S. 1400.

Laroque, Guy and Bernard Salanié, 2004, Fertility and Financial Incentives in France, CESifo Economic Studies 50(3), 423-450. 
Laroque, Guy and Bernard Salanié, 2014, Identifying the response of fertility to financial incentives, Journal of Applied Econometrics 29(2), 314-332.

Lüdeke, Rainer and Martin Werding, 1996, Die Reform des Dualen Familienlasten- bzw. Familienleistungsausgleichs 1996, Jahrbücher für Nationalökonomie und Statistik (Journal of Economics and Statistics) 215(4), 419-443.

Milligan, Kevin, 2005, Subsidizing the stork: new evidence on tax incentives and fertility, Review of Economics and Statistics 87(3), 539-555.

Moffitt, Robert, 1998, The effect of welfare on marriage and fertility, in: Moffitt R. (ed.) Welfare, the family and reproductive behavior: research perspectives, National Academy, Washington, 50-97.

OECD, 2014, OECD Family Database - PF1.3 Family cash benefits, www.oecd.org/els/soc /PF_1_3_Family_Cash_Benefits_Jul2013.pdf [last access 07 May 2016]

Rainer, Helmut, Stefan Bauernschuster, Natalia Danzer, Timo Hener, Christian Holzner, and Janina Reinkowski, 2012, Kindergeld, ifo Forschungsberichte, München.

Reuters, 2014, French government under fire over family benefit cuts, http://uk.reuters.com/ article/uk-france-benefits-idUKKCN0I60KY20141017 [last access 2016-May-23].

Schroedter, Julia H., Yvonne Lechert and Paul Lüttinger, 2006, Die Umsetzung der Bildungsskala ISCED-1997 für die Volkszählung 1970, die MikrozensusZusaterhebung 1971 und die Mikrozensen 1976-2004 (Version 1), mimeo, ZUMA, Mannheim.

STBA (Statistisches Bundesamt), 2016, Sozialleistungen - Elterngeld und Kindergeld, https://www.destatis.de/DE/ZahlenFakten/GesellschaftStaat/Soziales/Sozialleistungen/ Elterngeld/Tabellen/Kindergeld/EmpfaengerAusgaben.html [last access 2016-July-08].

Suzuki, Toru, 2013, Low Fertility and Population Aging in Japan and Eastern Asia, Springer Briefs in Population Studies, Tokyo et al..

Tamm, Marcus, 2010, Child Benefit Reform and Labor Market Participation, Journal of Economics and Statistics (Jahrbücher für Nationalökonomie und Statistik) 230(3), 313327.

Whittington, Leslie A., James Alm, and H. Elizabeth Peters, 1990, Fertility and the Personal Exemption: Implicit Pronatalist Policy in the United States, American Economic Review 80(3), 545-556.

Wagner, Gert G., Joachim R. Frick, and Jürgen Schupp, 2007, The German Socio-Economic Panel Study (SOEP) - Scope, Evolution and Enhancements, Schmollers Jahrbuch (Journal of Applied Social Science Studies), 127, 139-69. 
Table 1 Level of child benefits over time

\begin{tabular}{ccccc} 
Year & 1. Child & 2. Child & 3. Child & 4. Child and further \\
\hline \hline $1992-1993+$ & 70 & $70-130^{*}$ & $140-220^{*}$ & $140-220^{*}$ \\
$1994-1995+$ & 70 & $70-130^{*}$ & $70-220^{*}$ & $70-240^{*}$ \\
1996 & 200 & 200 & 300 & 350 \\
$1997-1998$ & 220 & 220 & 300 & 350 \\
1999 & 250 & 250 & 300 & 350 \\
$2000-2001$ & 270 & 270 & 300 & 350 \\
\hline
\end{tabular}

Notes: Benefits in DM per month; + marks the years in which the supplement payments of up to $65 \mathrm{DM}$ per month were paid to low income families; * marks income dependent cuts in child benefits.

Source: BMF 2008.

Table 2.1 Descriptive statistics of births for couples without children and with one child from the Mikrozensus by educational group

Couples without children

\begin{tabular}{|c|c|c|c|c|c|c|c|c|}
\hline & \multicolumn{2}{|c|}{ Narrow definition } & \multicolumn{2}{|c|}{ Broad definition } & \multicolumn{2}{|c|}{ Narrow definition } & \multicolumn{2}{|c|}{ Broad definition } \\
\hline & Low & High & Low & High & Low & High & Low & High \\
\hline $\mathrm{N}$ & 1,567 & 9,818 & 16,522 & 19,782 & 1,754 & 5,292 & 19,429 & 13,746 \\
\hline Births & 107 & 1,104 & 1,644 & 2,168 & 146 & 885 & 1,859 & 1,948 \\
\hline Birthrate prereform & $9.01 \%$ & $11.57 \%$ & $10.14 \%$ & $11.15 \%$ & $9.91 \%$ & $16.36 \%$ & $9.43 \%$ & $13.51 \%$ \\
\hline Birthrate postreform & $5.12 \%$ & $10.96 \%$ & $9.75 \%$ & $10.78 \%$ & $6.77 \%$ & $17.05 \%$ & $9.72 \%$ & $14.81 \%$ \\
\hline
\end{tabular}

Source: Own calculations based on the Mikrozensus waves 1995, 1996, 1998, and 1999.

Table 2.2 Descriptive statistics of births for couples without children and with one child from the SOEP by educational group

\begin{tabular}{|c|c|c|c|c|c|c|c|c|}
\hline & \multicolumn{4}{|c|}{ Couples without children } & \multicolumn{4}{|c|}{ Couples with one child } \\
\hline & \multicolumn{2}{|c|}{ Narrow definition } & \multicolumn{2}{|c|}{ Broad definition } & \multicolumn{2}{|c|}{ Narrow definition } & \multicolumn{2}{|c|}{ Broad definition } \\
\hline & Low & High & Low & High & Low & High & Low & High \\
\hline $\mathrm{N}$ & 42 & 272 & 573 & 651 & 58 & 204 & 832 & 582 \\
\hline Births & 2 & 31 & 61 & 80 & 3 & 29 & 82 & 80 \\
\hline Birthrate prereform & $7.14 \%$ & $13.33 \%$ & $11.46 \%$ & $13.21 \%$ & $3.33 \%$ & $16.67 \%$ & $8.43 \%$ & $13.74 \%$ \\
\hline Birthrate postreform & $3.57 \%$ & $9.87 \%$ & $9.82 \%$ & $11.59 \%$ & $7.14 \%$ & $12.28 \%$ & $11.36 \%$ & $13.75 \%$ \\
\hline
\end{tabular}

Source: Own calculations based on the SOEP waves 1992-1994 and 1996-1998. 
Table 3 Estimation results: reform effect on the propensity to have a first child based on Mikrozensus data

\begin{tabular}{lccccc} 
& \multicolumn{2}{c}{$\begin{array}{c}\text { High vs. Low Education } \\
\text { (Narrow Definition) }\end{array}$} & & \multicolumn{2}{c}{$\begin{array}{c}\text { High vs. Low Education } \\
\text { (Broad Definition) }\end{array}$} \\
\cline { 2 - 3 } \cline { 5 - 6 } & \multicolumn{1}{c}{1} & 2 & & 3 & 4 \\
\hline \hline \multirow{2}{*}{ Post Reform } & -0.006 & -0.010 & & -0.004 & -0.006 \\
& $(0.006)$ & $(0.008)$ & & $(0.004)$ & $(0.005)$ \\
Low Education & $-0.026^{* *}$ & -0.019 & & $-0.010^{* *}$ & $-0.011^{* *}$ \\
& $(0.012)$ & $(0.012)$ & & $(0.005)$ & $(0.005)$ \\
Low Educ.*Post Reform & $-0.033^{* *}$ & $-0.024^{*}$ & & -0.000 & 0.001 \\
& $(0.015)$ & $(0.015)$ & & $(0.006)$ & $(0.006)$ \\
Additional Controls & No & Yes & & No & Yes \\
$\mathrm{N}$ & 11,385 & 11,385 & & 36,304 & 36,304 \\
$\mathrm{R}^{2}$ & 0.0031 & 0.0489 & & 0.0003 & 0.0489 \\
\hline
\end{tabular}

Notes: Robust S.E. in parentheses, $* \mathrm{p}<0.10, * * \mathrm{p}<0.05, * * * \mathrm{p}<0.010$. The dependent variable in all models is birth in $t$. Its mean is 0.1063 in the narrow definition and 0.1050 in the broad definition. The additional controls are sets of dummies for mother's and partner's lagged age in steps of 4 years, lagged marital status, federal state, year of observation, and city size.

Source: Mikrozensus waves of 1995, 1996, 1998, and 1999, own calculations.

Table 4 Estimation results: reform effect on the propensity to have a second child based on Mikrozensus data

High vs. Low Education High vs. Low Education

\begin{tabular}{|c|c|c|c|c|}
\hline & \multicolumn{2}{|c|}{ (Narrow Definition) } & \multicolumn{2}{|c|}{ (Broad Definition) } \\
\hline & 1 & 2 & 3 & 4 \\
\hline Post Reform & $\begin{array}{c}-0.031 * * \\
(0.013)\end{array}$ & $\begin{array}{c}-0.045^{* * *} \\
(0.015)\end{array}$ & $\begin{array}{c}0.003 \\
(0.004)\end{array}$ & $\begin{array}{c}0.002 \\
(0.005)\end{array}$ \\
\hline High Education & $\begin{array}{c}0.065^{* * *} \\
(0.013)\end{array}$ & $\begin{array}{c}0.025^{* *} \\
(0.012)\end{array}$ & $\begin{array}{c}0.041^{* * *} \\
(0.005)\end{array}$ & $\begin{array}{c}0.030^{* * * *} \\
(0.005)\end{array}$ \\
\hline High Educ. *Post Reform & $\begin{array}{c}0.038^{* *} \\
(0.017)\end{array}$ & $\begin{array}{l}0.037^{* *} \\
(0.016)\end{array}$ & $\begin{array}{c}0.010 \\
(0.007)\end{array}$ & $\begin{array}{l}0.013^{*} \\
(0.007)\end{array}$ \\
\hline Additional Controls & No & Yes & No & Yes \\
\hline $\mathrm{N}$ & 7,046 & 7,046 & 33,175 & 33,175 \\
\hline $\mathrm{R}^{2}$ & 0.0111 & 0.1302 & 0.0052 & 0.1080 \\
\hline
\end{tabular}

Notes: Robust S.E. in parentheses, ${ }^{*} \mathrm{p}<0.10, * * \mathrm{p}<0.05, * * * \mathrm{p}<0.010$. The dependent variable in all models is birth in $t$. Its mean is 0.1463 in the narrow definition and 0.1147 in the broad definition. The additional controls are sets of dummies for mother's and partner's lagged age in steps of 4 years, lagged marital status, federal state, year of observation, city size, and the time passed since the woman's last birth.

Source: See Table 3. 


\begin{tabular}{|c|c|c|c|c|}
\hline \multirow[t]{3}{*}{ Table 5} & \multicolumn{4}{|c|}{ ults: reform effect on the propensity to have a first child based } \\
\hline & \multicolumn{2}{|c|}{$\begin{array}{l}\text { High vs. Low Education } \\
\text { (Narrow Definition) }\end{array}$} & \multicolumn{2}{|c|}{$\begin{array}{l}\text { High vs. Low Education } \\
\text { (Broad Definition) }\end{array}$} \\
\hline & 1 & 2 & 3 & 4 \\
\hline Post Reform & $\begin{array}{l}-0.035 \\
(0.040)\end{array}$ & $\begin{array}{l}-0.003 \\
(0.074)\end{array}$ & $\begin{array}{l}-0.016 \\
(0.026)\end{array}$ & $\begin{array}{c}0.000 \\
(0.041)\end{array}$ \\
\hline Low education & $\begin{array}{l}-0.062 \\
(0.069)\end{array}$ & $\begin{array}{l}-0.061 \\
(0.073)\end{array}$ & $\begin{array}{l}-0.018 \\
(0.028)\end{array}$ & $\begin{array}{l}-0.025 \\
(0.027)\end{array}$ \\
\hline Low educ. ${ }^{*}$ Post Reform & $\begin{array}{l}-0.001 \\
(0.081)\end{array}$ & $\begin{array}{l}-0.022 \\
(0.099)\end{array}$ & $\begin{array}{l}-0.000 \\
(0.036)\end{array}$ & $\begin{array}{l}-0.001 \\
(0.036)\end{array}$ \\
\hline Additional Controls & No & Yes & No & Yes \\
\hline $\mathrm{N}$ & 314 & 314 & 1,224 & 1,224 \\
\hline $\mathrm{R}^{2}$ & 0.0086 & 0.1160 & 0.0013 & 0.0823 \\
\hline
\end{tabular}

Notes: Robust S.E., clustered by person, in parentheses, ${ }^{*} \mathrm{p}<0.10,{ }^{* *} \mathrm{p}<0.05, * * * \mathrm{p}<0.010$. The dependent variable in all models is birth in $t+1$. Its mean is 0.1061 in the narrow definition and 0.1151 in the broad definition. The additional controls are sets of dummies for mother's and partner's age in steps of 4 years, marital status, federal state, and month and year of observation.

Source: Own calculations based on the SOEP waves 1992-1994 and 1996-1998.

Table 6 Estimation results: reform effect on the propensity to have a second child based on SOEP data

\begin{tabular}{lccccc} 
& \multicolumn{2}{c}{$\begin{array}{c}\text { High vs. Low Education } \\
\text { (Narrow Definition) }\end{array}$} & & \multicolumn{2}{c}{$\begin{array}{c}\text { High vs. Low Education } \\
\text { (Broad Definition) }\end{array}$} \\
\cline { 2 - 3 } \cline { 5 - 6 } & \multicolumn{1}{c}{1} & 2 & & 3 & 4 \\
\hline \hline \multirow{2}{*}{ Post Reform } & 0.038 & $0.146^{*}$ & & 0.029 & 0.035 \\
& $(0.057)$ & $(0.086)$ & & $(0.020)$ & $(0.033)$ \\
High Education & $0.133^{* * *}$ & $0.143^{* *}$ & & $0.053^{* *}$ & 0.029 \\
& $(0.049)$ & $(0.069)$ & & $(0.025)$ & $(0.026)$ \\
High Ed.*Post Reform & -0.082 & -0.108 & & -0.029 & -0.036 \\
& $(0.074)$ & $(0.087)$ & & $(0.034)$ & $(0.034)$ \\
Additional Controls & No & Yes & & No & Yes \\
$\mathrm{N}$ & 262 & 262 & & 1,414 & 1,414 \\
$\mathrm{R}^{2}$ & 0.0173 & 0.1323 & & 0.0049 & 0.0846 \\
\hline
\end{tabular}

Notes: Robust S.E., clustered by person, in parentheses, ${ }^{*} \mathrm{p}<0.10, * * \mathrm{p}<0.05, * * * \mathrm{p}<0.010$. The dependent variable in all models is birth in $t+1$. Its mean is 0.1270 in the narrow definition and 0.1164 in the broad definition. The additional controls are sets of dummies for mother's and partner's age in steps of 4 years, marital status, federal state, month and year of observation and categorical indicators of birth spacing.

Source: See Table 5. 
Table 7 Estimation results: reform effect on the propensity to have a first or second child based on Mikrozensus data; treatment and control groups defined by household income in the highest vs. lowest quartile

\begin{tabular}{|c|c|c|c|c|}
\hline & \multicolumn{2}{|c|}{$\begin{array}{c}\text { High vs. Low Income } \\
\text { No Children }\end{array}$} & \multicolumn{2}{|c|}{$\begin{array}{c}\text { High vs. Low Income } \\
\text { One Child }\end{array}$} \\
\hline & 1 & 2 & 3 & 4 \\
\hline Post Reform & $\begin{array}{l}-0.001 \\
(0.005)\end{array}$ & $\begin{array}{l}-0.003 \\
(0.007)\end{array}$ & $\begin{array}{l}0.001 \\
(0.007)\end{array}$ & $\begin{array}{c}0.005 \\
(0.008)\end{array}$ \\
\hline Low Income & $\begin{array}{c}0.161^{* * *} \\
(0.007)\end{array}$ & $\begin{array}{c}0.152^{* * *} \\
(0.007)\end{array}$ & - & - \\
\hline Low Inc.*Post Reform & $\begin{array}{c}0.001 \\
(0.010)\end{array}$ & $\begin{array}{c}0.003 \\
(0.010)\end{array}$ & - & - \\
\hline High Income & - & - & $\begin{array}{c}-0.044 * * * \\
(0.007)\end{array}$ & $\begin{array}{c}-0.031 * * * \\
(0.007)\end{array}$ \\
\hline High Inc. *Post Reform & - & - & $\begin{array}{c}0.012 \\
(0.010)\end{array}$ & $\begin{array}{c}0.006 \\
(0.009)\end{array}$ \\
\hline Additional Controls & No & Yes & No & Yes \\
\hline $\mathrm{N}$ & 17,850 & 17,850 & 16,818 & 16,818 \\
\hline $\mathrm{R}^{2}$ & 0.0567 & 0.1251 & 0.0038 & 0.1109 \\
\hline
\end{tabular}

Notes: Robust S.E. in parentheses, ${ }^{*} \mathrm{p}<0.10, * * \mathrm{p}<0.05, * * * \mathrm{p}<0.010$. The dependent variable in all models is birth in $t$. Its mean is 0.1332 for couples without children and 11.17 for couples with one child. "Low Income" and "High Income" are dummies, indicating that a family is in the lowest or highest income quartile in the sample. The middle quartiles are not part of the sample. The additional controls are sets of dummies for mother's and partner's lagged age in steps of 4 years, lagged marital status, federal state, year of observation, and city size. Column 4 additionally considers categorical indicators of birth spacing.

Source: See Table 3. 
Table 8 Estimation results: reform effect on the propensity to have a first child based on Mikrozensus data with an extended sample

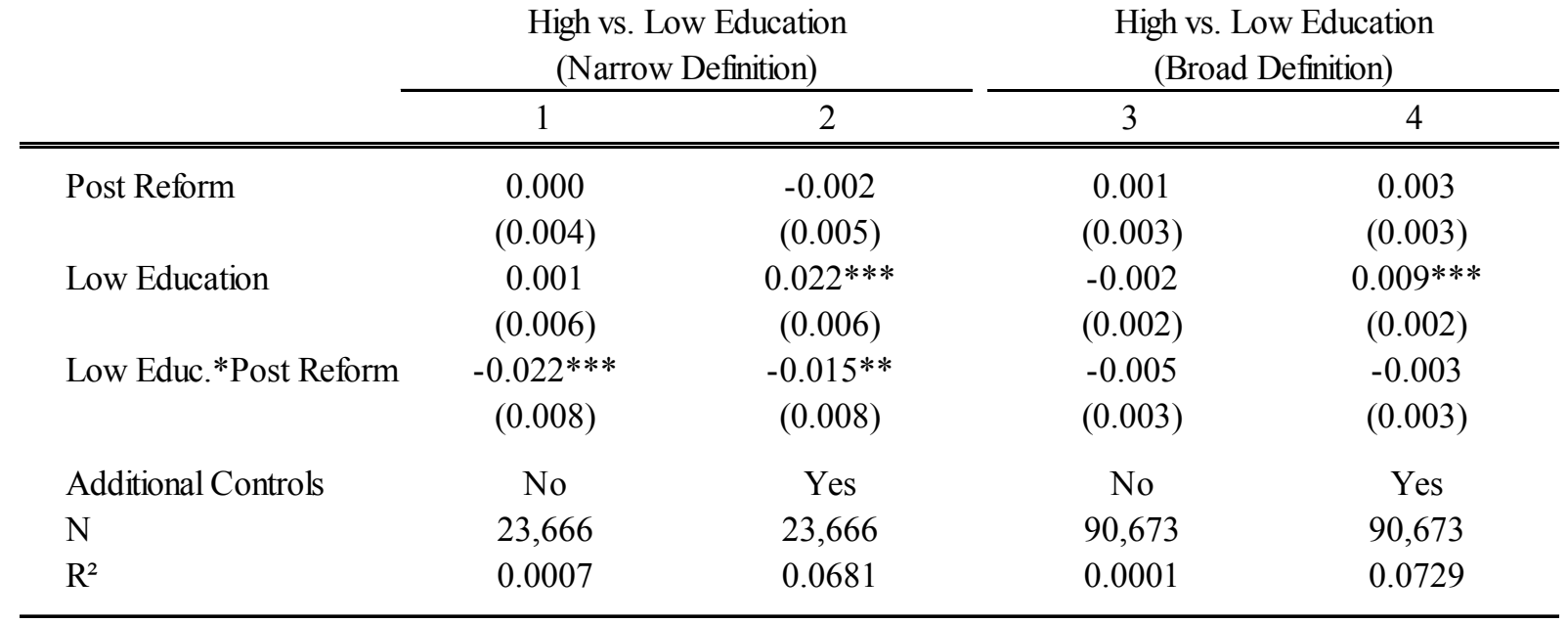

Notes: Robust S.E. in parentheses, ${ }^{*} \mathrm{p}<0.10,{ }^{* *} \mathrm{p}<0.05,{ }^{* * *} \mathrm{p}<0.010$. The dependent variable in all models is birth in $t$. Its mean is 0.0783 in the narrow definition and 0.0709 in the broad definition. The additional controls are sets of dummies for mother's and partner's lagged age in steps of 4 years, lagged marital status, federal state, year of observation, and city size.

Source: Mikrozensus waves of 1995, 1996, 1998 and 1999, own calculations.

Table 9 Estimation results: reform effect on the propensity to have a second child based on Mikrozensus data with an extended sample

\begin{tabular}{lccccc} 
& \multicolumn{2}{c}{$\begin{array}{c}\text { High vs. Low Education } \\
\text { (Narrow Definition) }\end{array}$} & & \multicolumn{2}{c}{$\begin{array}{c}\text { High vs. Low Education } \\
\text { (Broad Definition) }\end{array}$} \\
\cline { 2 - 3 } \cline { 5 - 6 } & \multicolumn{1}{c}{1} & 2 & & 3 & 4 \\
\hline \hline \multirow{2}{*}{ Post Reform } & -0.007 & -0.009 & & -0.001 & $0.006^{* *}$ \\
& $(0.007)$ & $(0.007)$ & & $(0.002)$ & $(0.003)$ \\
High Education & 0.007 & 0.009 & & $0.008^{* * *}$ & $0.011^{* * *}$ \\
& $(0.006)$ & $(0.006)$ & & $(0.002)$ & $(0.002)$ \\
High Educ.*Post Reform & $0.015^{*}$ & 0.013 & & $0.011^{* * *}$ & $0.010^{* * *}$ \\
& $(0.008)$ & $(0.008)$ & & $(0.004)$ & $(0.003)$ \\
Additional Controls & No & Yes & & No & Yes \\
$\mathrm{N}$ & 18,780 & 18,780 & & 84,719 & 84,719 \\
$\mathrm{R}^{2}$ & 0.0007 & 0.1388 & & 0.0009 & 0.1232 \\
\hline
\end{tabular}

Notes: Robust S.E. in parentheses, ${ }^{*} \mathrm{p}<0.10, * * \mathrm{p}<0.05, * * * \mathrm{p}<0.010$. The dependent variable in all models is birth in $t$. Its mean is 0.0847 in the narrow definition and 0.0669 in the broad definition. The additional controls are sets of dummies for mother's and partner's lagged age in steps of 4 years, lagged marital status, federal state, year of observation, city size and categorical indicators of birth spacing. Source: See Table 8. 
Table 10 Estimation results: reform effect on the propensity to have a first child based on Mikrozensus data considering welfare vs. nonwelfare recipients

\begin{tabular}{|c|c|c|c|c|c|c|}
\hline & \multicolumn{2}{|c|}{$\begin{array}{l}\text { Welfare vs. No Welfare } \\
\text { Sample: Lowly Educated } \\
\text { (Narrow Defintion) }\end{array}$} & \multicolumn{2}{|c|}{$\begin{array}{c}\text { Welfare vs. No Welfare } \\
\text { Sample: Lowly Educated } \\
\text { (Broad Defintion) }\end{array}$} & \multicolumn{2}{|c|}{$\begin{array}{l}\text { Welfare vs. No Welfare } \\
\text { Sample: All Observations }\end{array}$} \\
\hline & 1 & 2 & 3 & 4 & 5 & 6 \\
\hline Post Reform & $\begin{array}{c}0.021 \\
(0.021)\end{array}$ & $\begin{array}{l}0.050^{*} \\
(0.030)\end{array}$ & $\begin{array}{l}-0.012 \\
(0.030)\end{array}$ & $\begin{array}{c}0.009 \\
(0.031)\end{array}$ & $\begin{array}{l}-0.034 \\
(0.033)\end{array}$ & $\begin{array}{l}-0.026 \\
(0.032)\end{array}$ \\
\hline No welfare receipt & $\begin{array}{c}0.090 * * * \\
(0.011)\end{array}$ & $\begin{array}{c}0.087 * * * \\
(0.016)\end{array}$ & $\begin{array}{l}0.039^{*} \\
(0.023)\end{array}$ & $\begin{array}{l}-0.004 \\
(0.023)\end{array}$ & $\begin{array}{c}0.003 \\
(0.026)\end{array}$ & $\begin{array}{l}-0.042 * \\
(0.025)\end{array}$ \\
\hline No welf. rec.*Post Reform & $\begin{array}{c}-0.060^{* *} \\
(0.025)\end{array}$ & $\begin{array}{c}-0.084^{* * * *} \\
(0.029)\end{array}$ & $\begin{array}{c}0.007 \\
(0.031)\end{array}$ & $\begin{array}{l}-0.009 \\
(0.030)\end{array}$ & $\begin{array}{c}0.031 \\
(0.033)\end{array}$ & $\begin{array}{c}0.021 \\
(0.032)\end{array}$ \\
\hline Additional Controls & No & Yes & No & Yes & No & Yes \\
\hline $\mathrm{N}$ & 1,666 & 1,666 & 16,115 & 16,115 & 36,605 & 36,605 \\
\hline $\mathrm{R}^{2}$ & 0.0090 & 0.0861 & 0.0004 & 0.0604 & 0.0001 & 0.0498 \\
\hline
\end{tabular}

Notes: Robust S.E. in parentheses, $* \mathrm{p}<0.10, * * \mathrm{p}<0.05, * * * \mathrm{p}<0.010$. The dependent variable in all models is birth in $t$. Its mean is 0.0648 in the sample of columns 1 and 2, 0.0985 in columns 3 and 4 and 0.1048 columns 5 and 6. Columns 1 and 2 show the results for couples with low education in the narrow definition, with and without controls, respectively. Here the control group are low educated welfare recipients and the treatment group are the low educated who do not receive welfare. Columns 3 and 4 show the same for couples with low education in the broad definition and columns 5 and 6 for all couples, regardless of education. The additional controls are sets of dummies for mother's and partner's lagged age in steps of 4 years, lagged marital status, federal state, year of observation and city size.

Source: See Table 3. 
Figure 1.1 Absolute net transfer for a first child

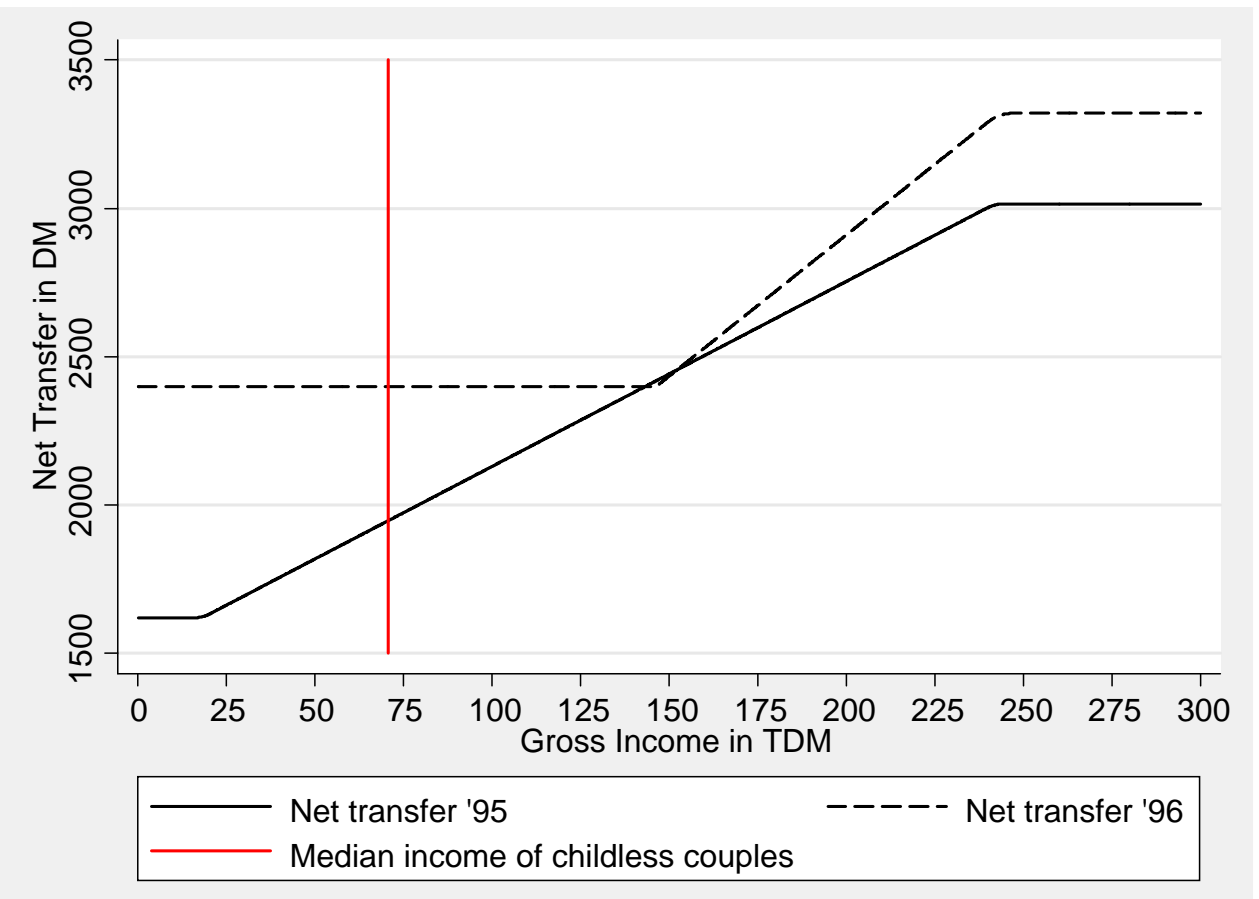

Figure 1.2 Relative net transfer for a first child

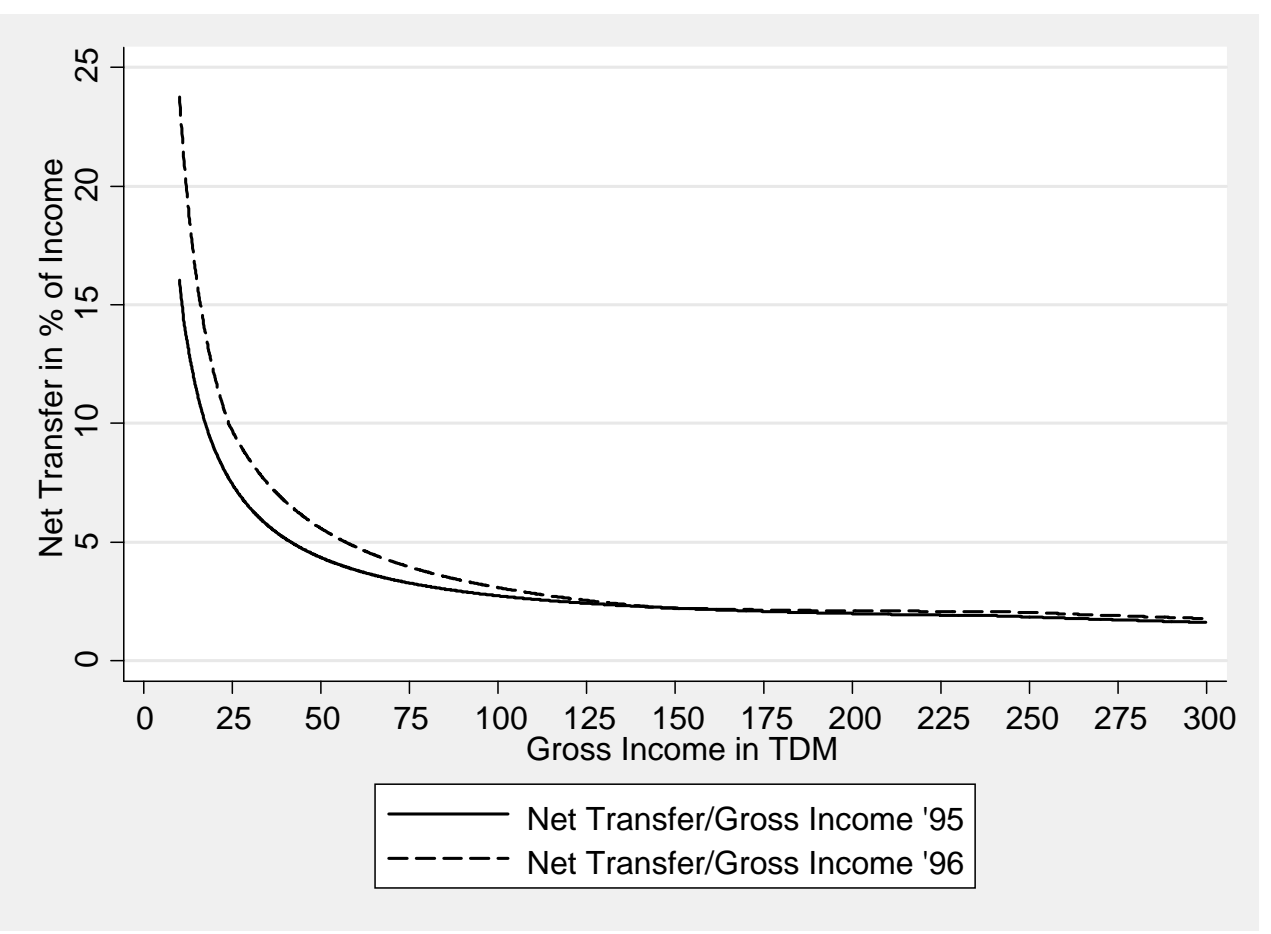

Notes: The gross income refers to yearly gross household income. Net transfer stands for the combined amount of tax savings, child benefits, and child benefit supplements a married couple with no previous children would receive if the family had a first child. The vertical line in Figure 1.1 marks the imputed median gross income of the Mikrozensus sample of couples at risk of a first birth. The imputation is based on net income figures and own calculations.

Source: Own calculations based on income tax laws and child benefit regulations. 


\section{Figure 2.1 Absolute net transfer for a second child}

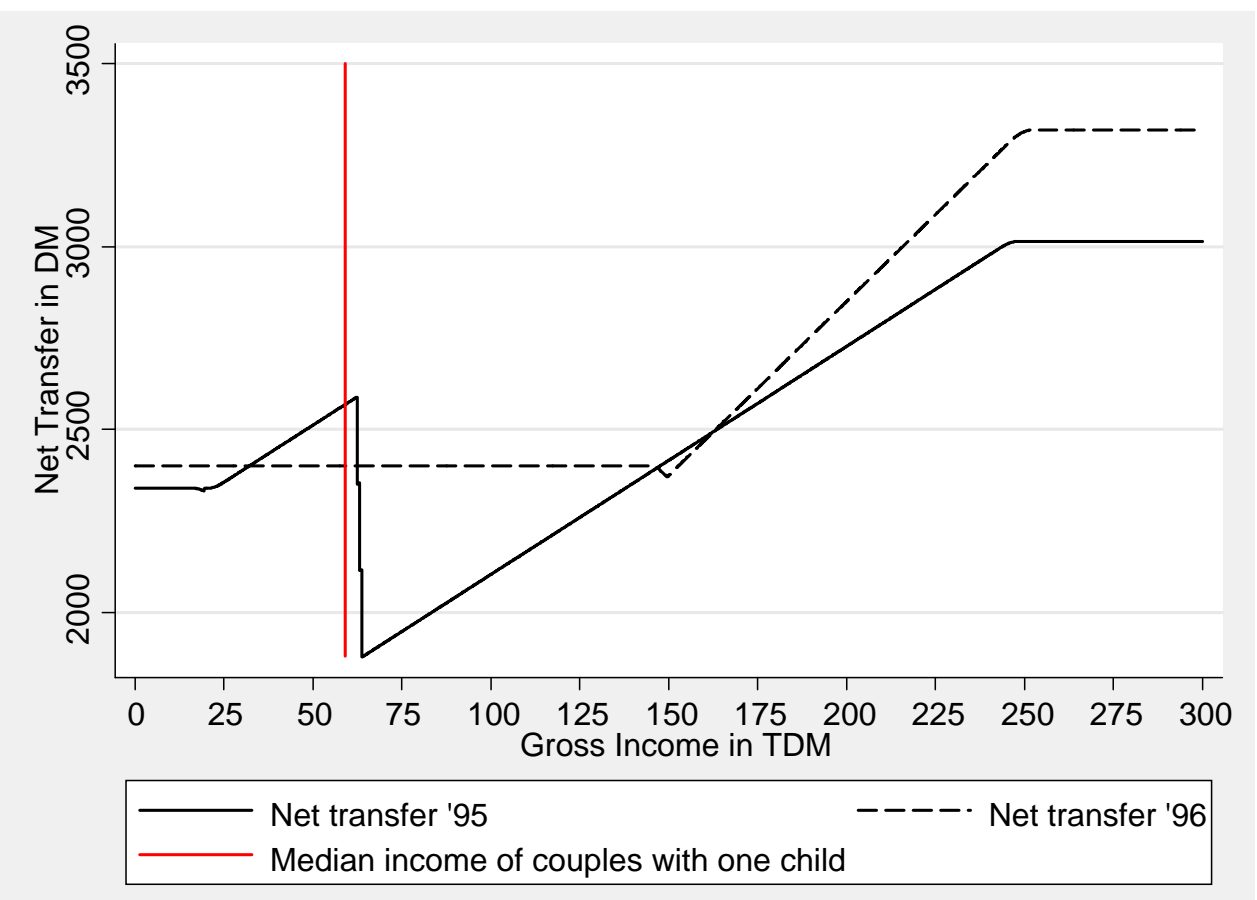

Figure 2.2 Relative net transfer for a second child

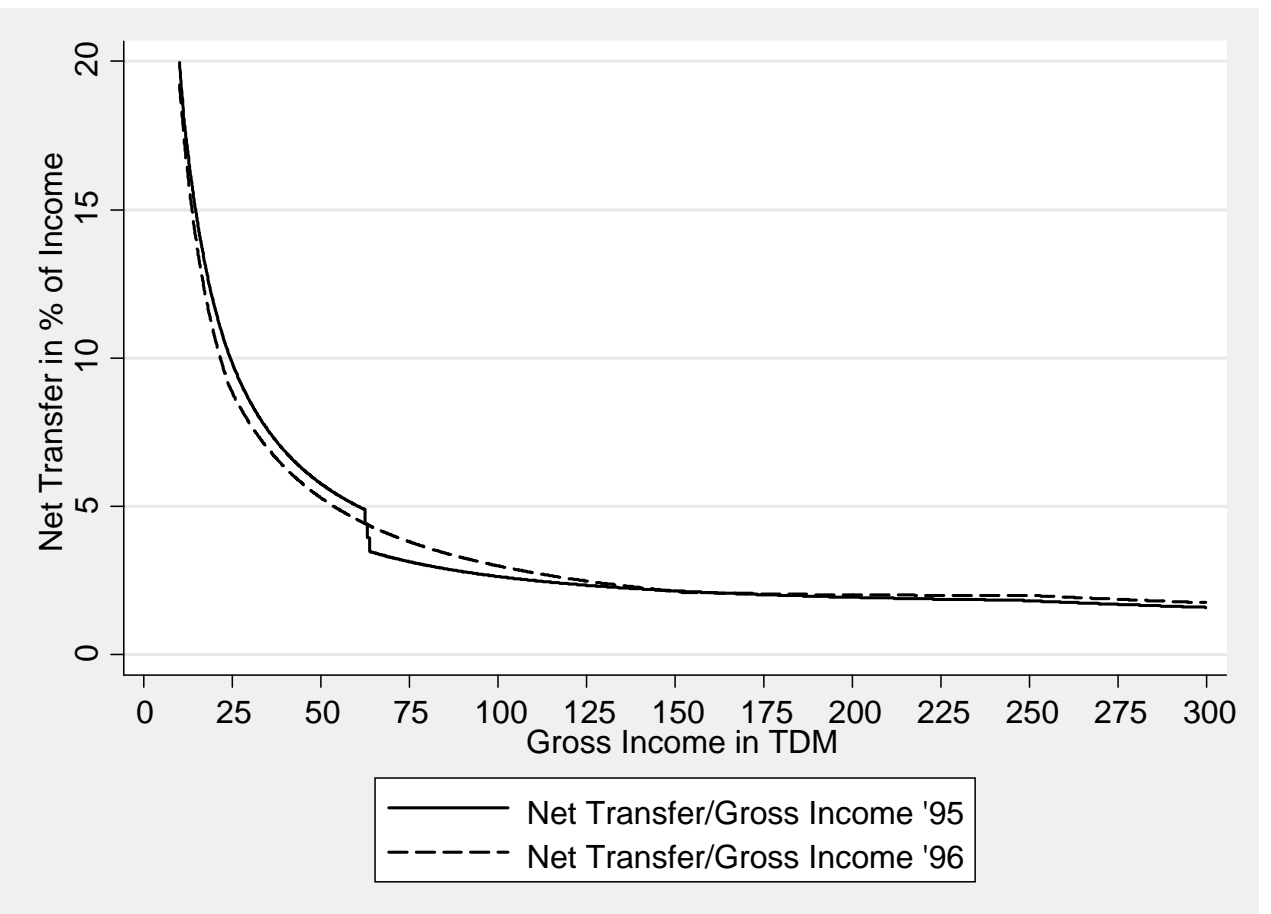

Notes: The gross income refers to yearly gross household income. Net transfer stands for the combined amount of tax savings, child benefits, and child benefit supplements a married couple with one previous child would receive if the family had a second child. The vertical line in Figure 2.1 marks the imputed median gross income of the Mikrozensus sample of couples at risk of a second birth. The imputation is based on net income figures and own calculations.

Source: Own calculations. 
Figure 3 Absolute net transfer for a third child

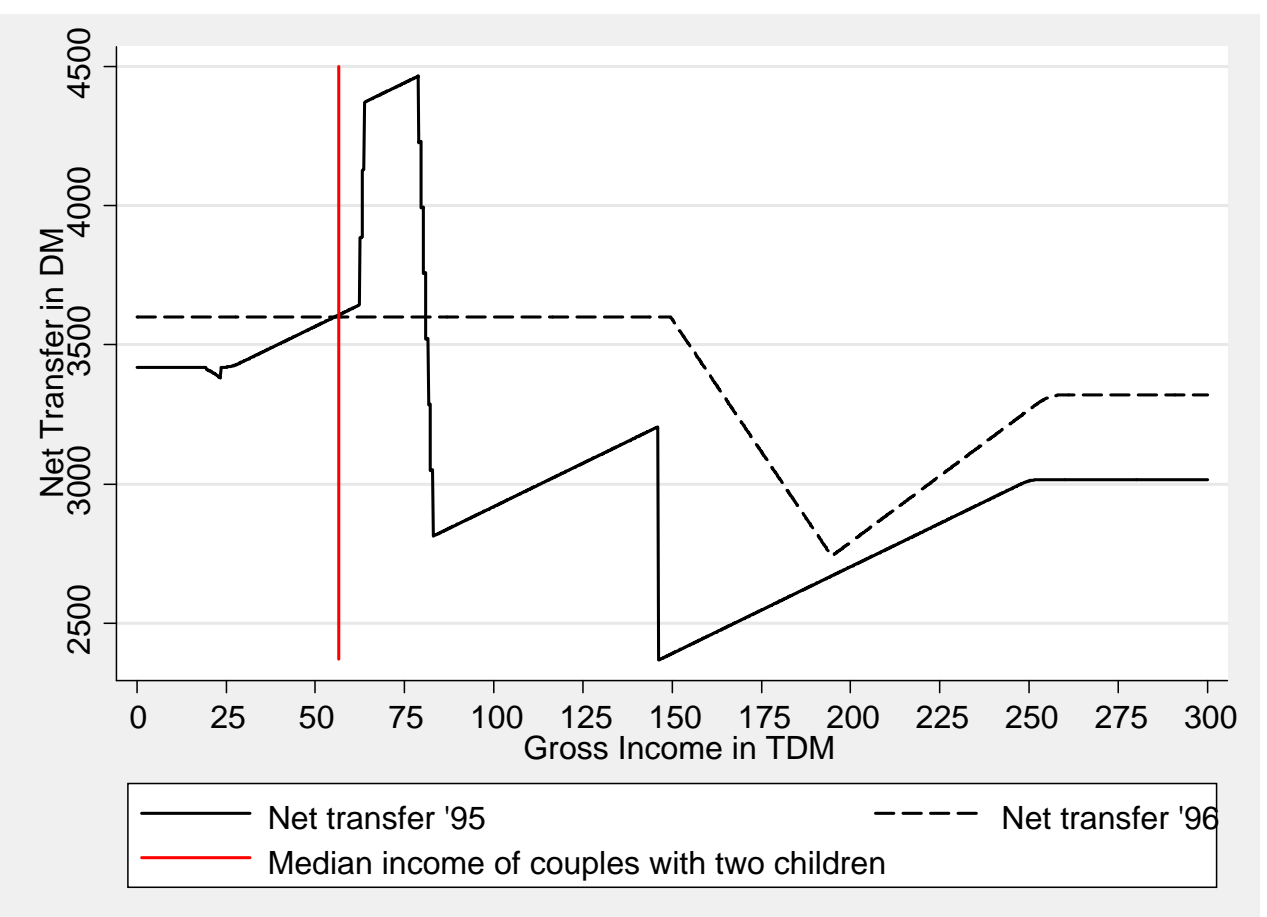

Notes: The gross income refers to yearly gross household income. Net transfer stands for the combined amount of tax savings, child benefits, and child benefit supplements a married couple with two previous children would receive if the family had a third child. The vertical line marks the imputed median gross income of the Mikrozensus sample of couples at risk of a third birth. The imputation is based on net income figures and own calculations.

Source: Own calculations. 
Figure 4.1 Birthrates of childless married couples by educational groups in the narrow definition of education

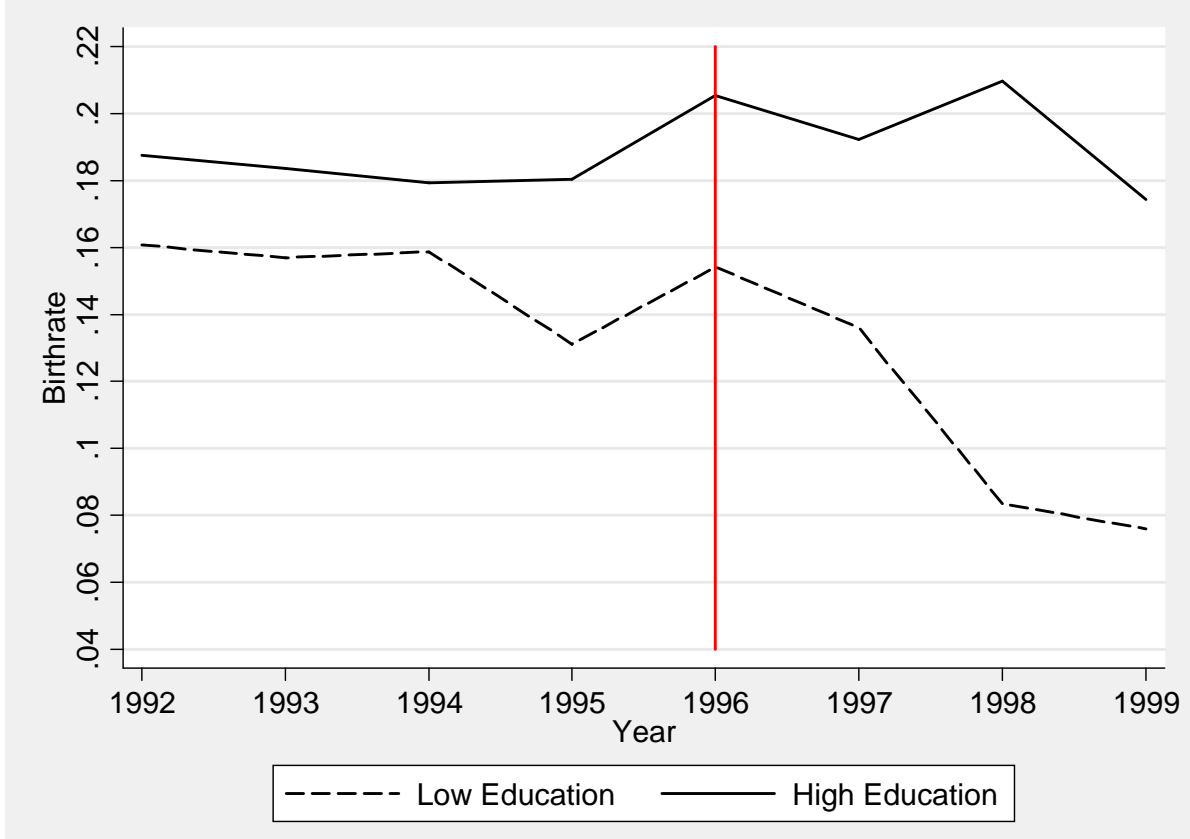

Figure 4.2 Birthrates of childless married couples by educational groups in the broad definition of education

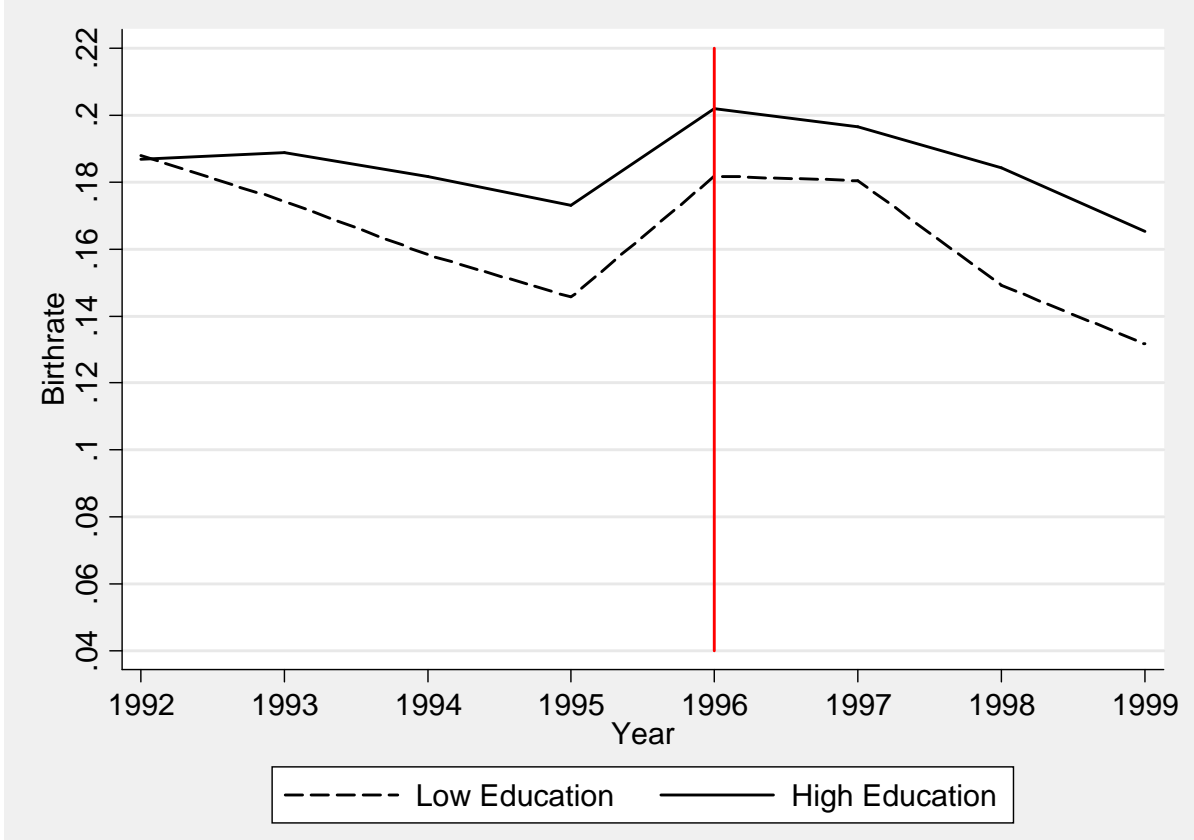


Figure 4.3 Birthrates of married couples with one child by educational groups in the narrow definition of education

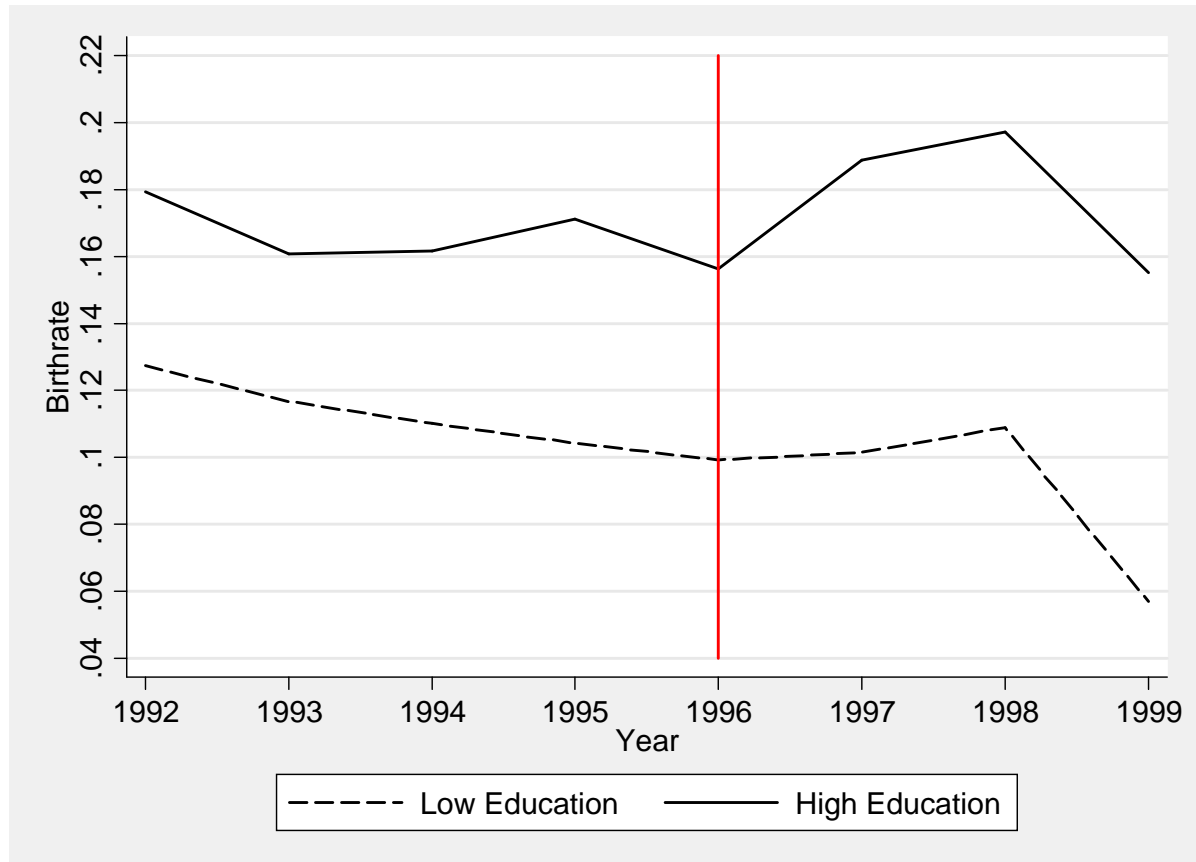

Figure 4.4 Birthrates of married couples with one child by educational groups in the broad definition of education

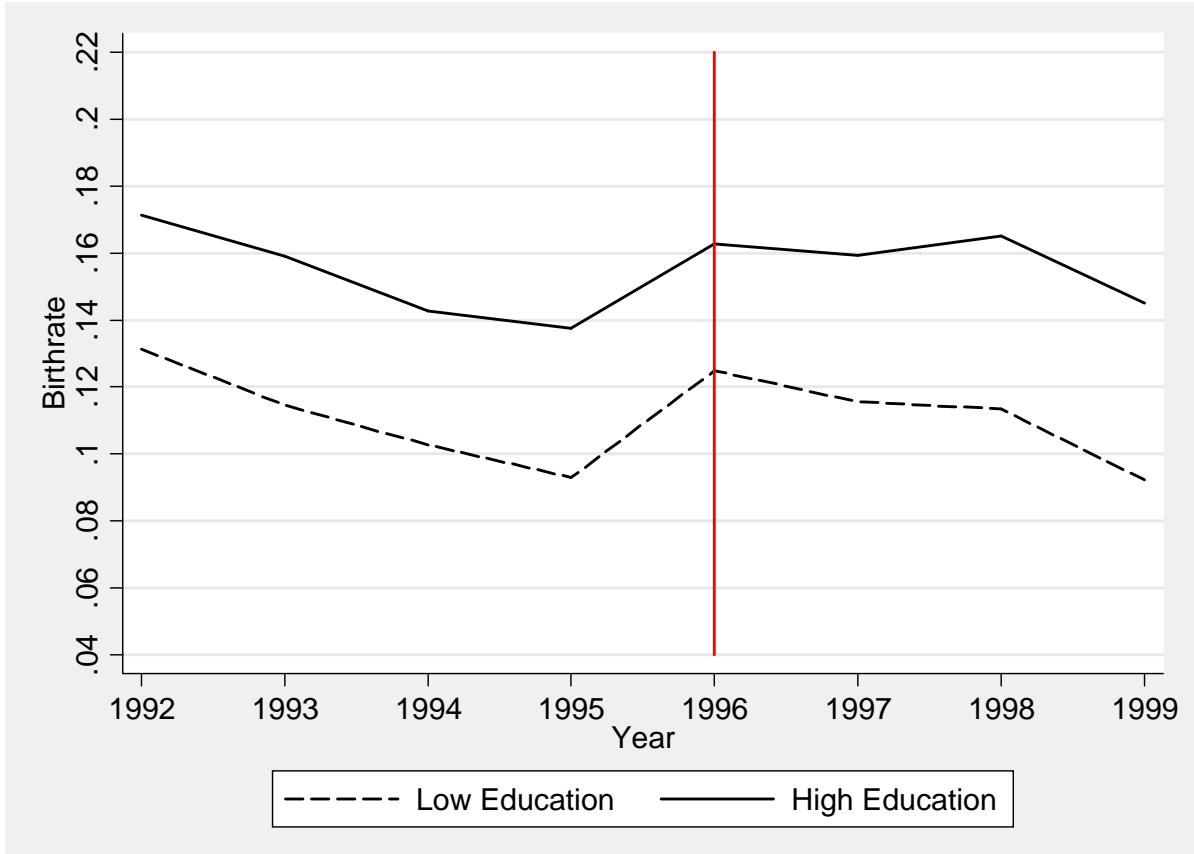

Notes: The sample used to create these graphs is described in Section 4.1. 'Year' does corresponds to the Mikrozensus survey dates. The vertical line marks the last period that is unaffected by the reform. Source: Mikrozensus waves 1995 and 1999, own calculations. 
Figure 5.1 Income distribution of childless couples by educational groups in the narrow definition

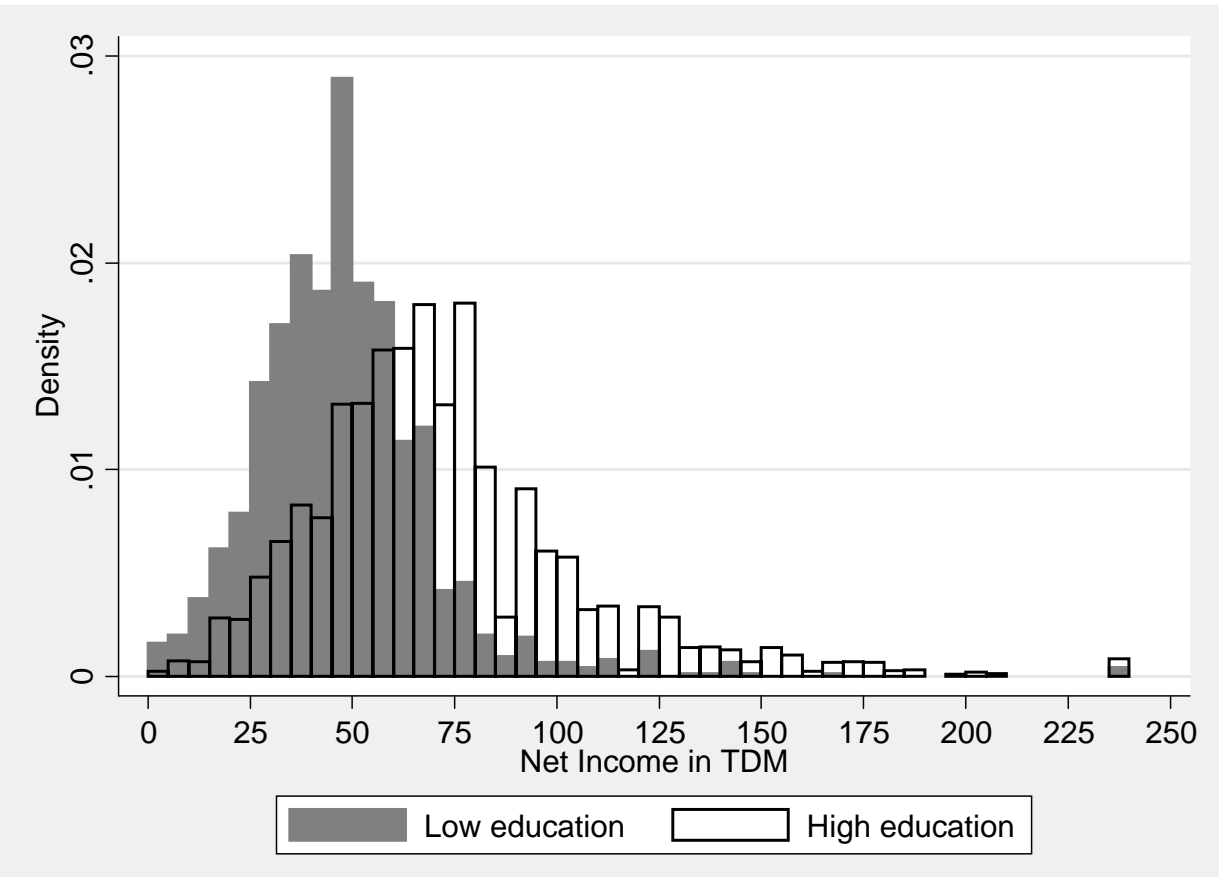

Figure 5.2 Income distribution of couples with one child by educational groups in the narrow definition

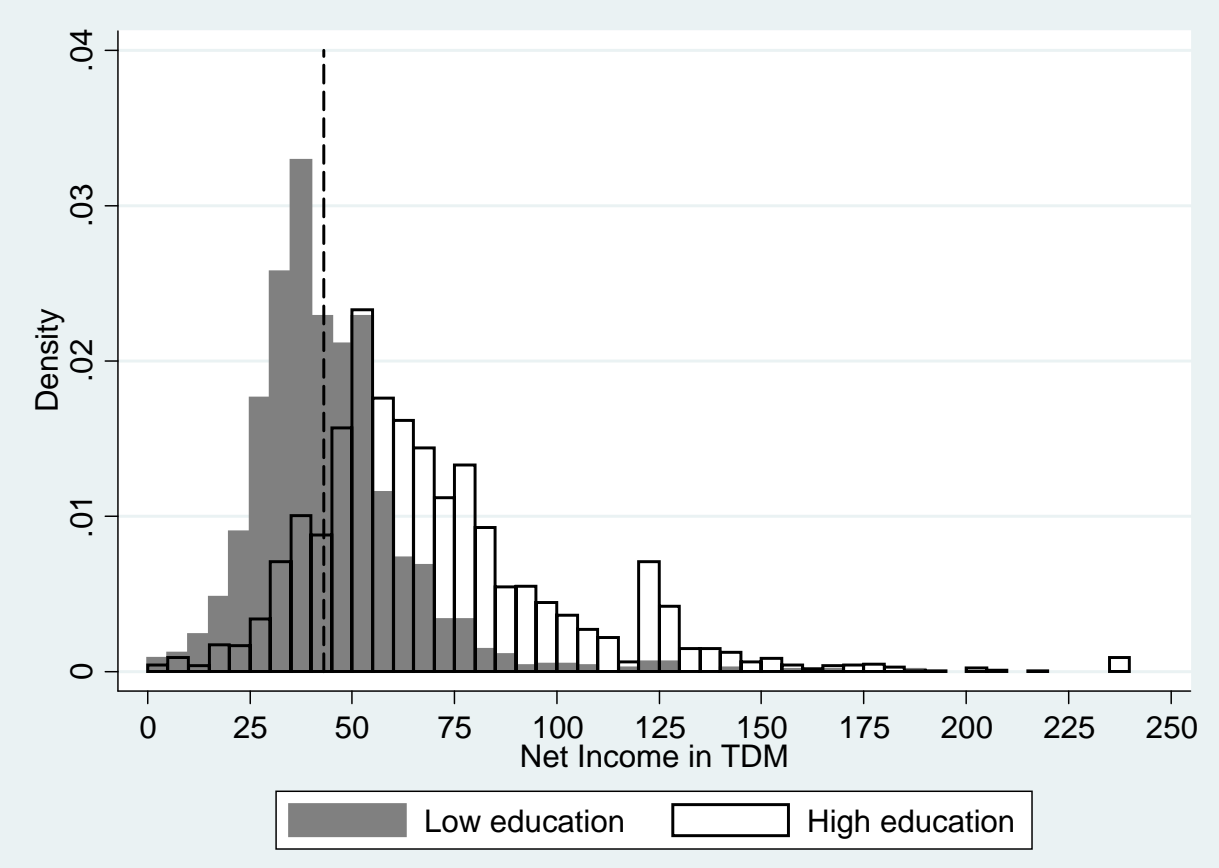


Figure 5.3 Income distribution of childless couples by educational groups in the broad definition

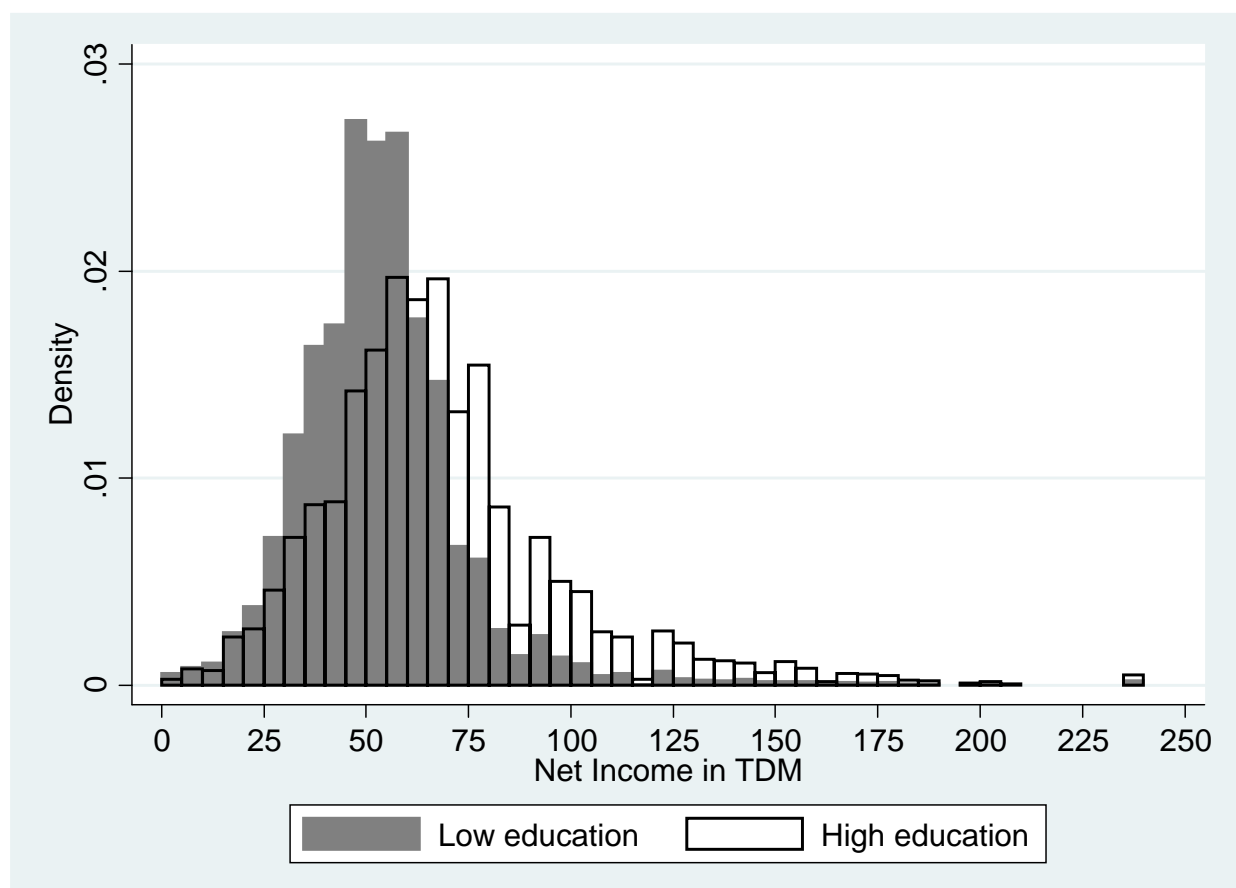

Figure 5.4 Income distribution of couples with one child by educational groups in the broad definition

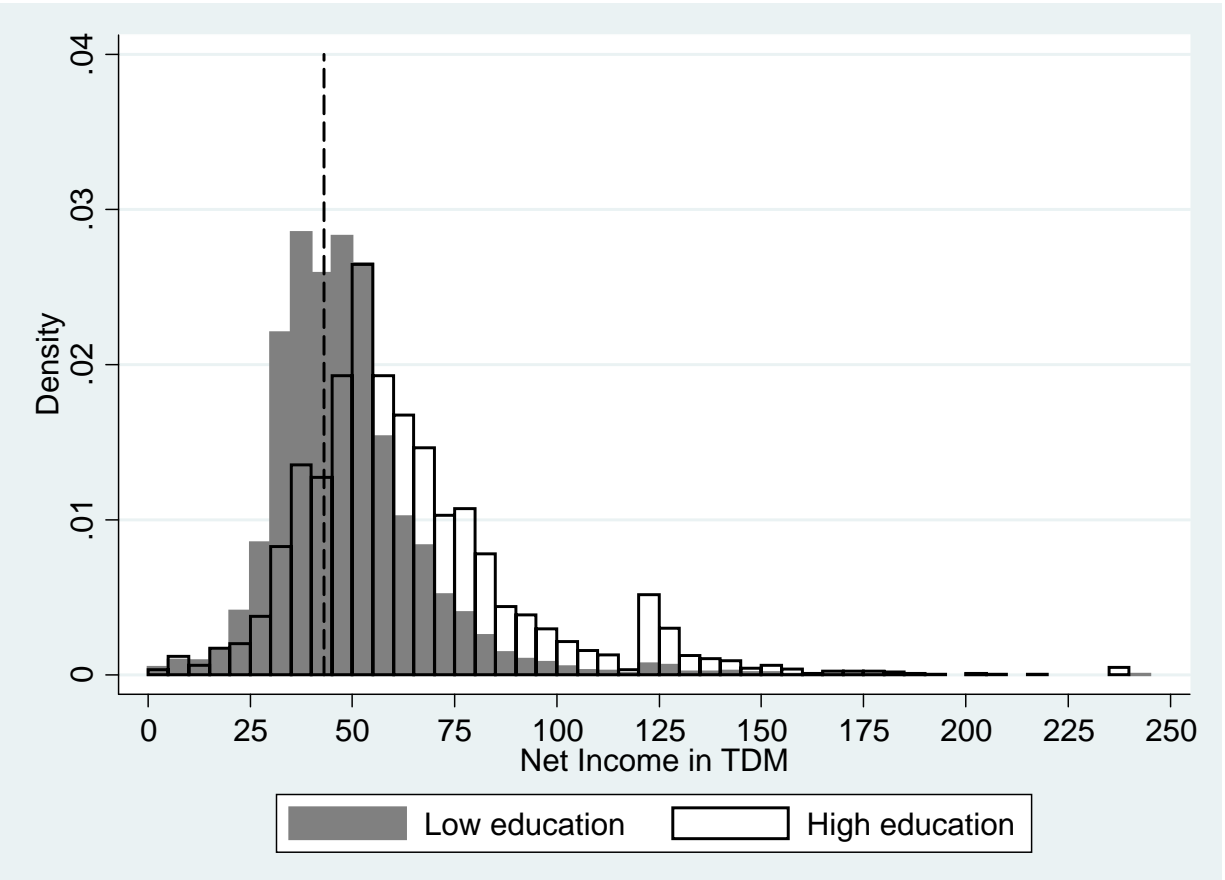

Notes: We report income in net amounts because the Mikrozensus does not contain information on gross income. The dashed lines in Figures 5.2 and 5.4 represent the threshold of 43,000 DM, which is the approximate limit that divides one-child families into beneficiaries and losers of the reform in terms of increased net transfers for a second child (which lies at 63,000 DM in terms of gross income).

Source: Own calculations based on the Mikrozensus waves 1995, 1996, 1998, and 1999. 


\section{Appendix A - Additional Descriptives and Estimation Results}

\section{Table A.1 The ISCED 1997-Scale}

\begin{tabular}{lcccc} 
& \multicolumn{5}{c}{ Vocational/University degree } \\
\cline { 2 - 5 } School degree & $\begin{array}{c}\text { No } \\
\text { degree }\end{array}$ & $\begin{array}{c}\text { Vocational } \\
\text { degree }\end{array}$ & $\begin{array}{c}\text { Higher voca- } \\
\text { tional degree }\end{array}$ & $\begin{array}{c}\text { University } \\
\text { degree }\end{array}$ \\
\hline \hline No degree & 1 & 3 & 5 & 6 \\
\hline High school diploma & 2 & 3 & 5 & 6 \\
\hline Secondary school diploma & 3 & 4 & 5 & 6 \\
\hline
\end{tabular}

Source: Based on Schroedter et al. 2006 and the ISCED-1997 coding in the SOEP. 
Table A.2 Descriptive statistics of explanatory variables: couples without children; broad definition of educational groups; Mikrozensus

\begin{tabular}{|c|c|c|c|c|c|}
\hline & Low & High & & Low & High \\
\hline $\mathbf{N}$ & 16,522 & 19,782 & & & \\
\hline Married in $\mathrm{t}-1$ & $50.18 \%$ & $42.55 \%$ & & & \\
\hline \multicolumn{3}{|l|}{ ISCED mother } & \multicolumn{3}{|l|}{ ISCED partner } \\
\hline 1 (inadequately) & $1.07 \%$ & $0.06 \%$ & 1 (inadequately) & $0.93 \%$ & $0.06 \%$ \\
\hline 2 (general elementary) & $18.98 \%$ & $3.08 \%$ & 2 (general elementary) & $14.37 \%$ & $1.24 \%$ \\
\hline 3 (upper sec. or voc.) & $79.95 \%$ & $29.72 \%$ & 3 (upper sec. or voc.) & $84.71 \%$ & $16.21 \%$ \\
\hline 4 (upper sec. and voc.) & - & $21.06 \%$ & 4 (upper sec. and voc.) & - & $12.38 \%$ \\
\hline 5 (higher vocational) & - & $11.28 \%$ & 5 (higher vocational) & - & $22.27 \%$ \\
\hline 6 (higher education) & - & $34.80 \%$ & 6 (higher education) & - & $47.84 \%$ \\
\hline \multicolumn{3}{|l|}{ Age of mother in $t-1$} & \multicolumn{3}{|l|}{ Age of partner in t-1 } \\
\hline$<=20$ & - & - & $<=20$ & $0.16 \%$ & $0.08 \%$ \\
\hline $21-24$ & - & - & $21-24$ & $2.71 \%$ & $1.81 \%$ \\
\hline $25-28$ & $35.14 \%$ & $36.61 \%$ & $25-28$ & $17.70 \%$ & $19.21 \%$ \\
\hline $29-32$ & $27.16 \%$ & $31.74 \%$ & $29-32$ & $25.59 \%$ & $30.49 \%$ \\
\hline $33-36$ & $19.16 \%$ & $18.30 \%$ & $33-36$ & $20.14 \%$ & $21.01 \%$ \\
\hline $37-40$ & $18.54 \%$ & $13.36 \%$ & $37-40$ & $14.80 \%$ & $13.48 \%$ \\
\hline $41-44$ & - & - & $41-44$ & $9.65 \%$ & $7.24 \%$ \\
\hline $45-49$ & - & - & $45-49$ & $5.26 \%$ & $3.92 \%$ \\
\hline$>=50$ & - & - & $>=49$ & $4.00 \%$ & $2.77 \%$ \\
\hline \multicolumn{6}{|l|}{ State of residence } \\
\hline Schleswig-Holstein & $5.37 \%$ & $4.70 \%$ & & & \\
\hline Hamburg & $2.40 \%$ & $3.64 \%$ & & & \\
\hline Niedersachsen & $12.00 \%$ & $10.03 \%$ & & & \\
\hline Bremen & $1.03 \%$ & $0.91 \%$ & & & \\
\hline Nordrhein-Westfalen & $28.76 \%$ & $28.28 \%$ & & & \\
\hline Hessen & $8.23 \%$ & $9.86 \%$ & & & \\
\hline Rheinland-Pfalz & $6.27 \%$ & $5.57 \%$ & & & \\
\hline Baden-Wuertemberg & $13.12 \%$ & $14.83 \%$ & & & \\
\hline Bayern & $18.52 \%$ & $17.05 \%$ & & & \\
\hline Saarland & $1.72 \%$ & $1.31 \%$ & & & \\
\hline Berlin & $2.57 \%$ & $3.82 \%$ & & & \\
\hline \multicolumn{3}{|c|}{ Community/City size in thousands } & & & \\
\hline$<20$ & $42.79 \%$ & $33.26 \%$ & & & \\
\hline $20-100$ & $27.86 \%$ & $27.22 \%$ & & & \\
\hline $100-500$ & $16.01 \%$ & $19.05 \%$ & & & \\
\hline$>500$ & $13.34 \%$ & $20.46 \%$ & & & \\
\hline
\end{tabular}

Source: Own calculations based on the Mikrozensus waves 1995, 1996, 1998, and 1999. 
Table A.3 Descriptive statistics of explanatory variables: couples with one child; broad definition of educational groups; Mikrozensus

\begin{tabular}{|c|c|c|c|c|c|}
\hline & Low & High & & Low & High \\
\hline $\begin{array}{l}\mathrm{N} \\
\text { Married in t-1 } \\
\text { ISCED mother }\end{array}$ & $\begin{array}{c}19,429 \\
83.91 \%\end{array}$ & $\begin{array}{c}13,746 \\
83.54 \%\end{array}$ & \multicolumn{3}{|l|}{ ISCED partner } \\
\hline $\begin{array}{l}1 \text { (inadequately) } \\
2 \text { (general elementary) } \\
3 \text { (upper sec. or voc.) } \\
4 \text { (upper sec. and voc.) } \\
5 \text { (higher vocational) } \\
6 \text { (higher education) }\end{array}$ & $\begin{array}{c}1.12 \% \\
21.93 \% \\
76.95 \% \\
- \\
- \\
-\end{array}$ & $\begin{array}{c}0.17 \% \\
5.22 \% \\
39.35 \% \\
19.38 \% \\
11.90 \% \\
23.98 \%\end{array}$ & $\begin{array}{l}1 \text { (inadequately) } \\
2 \text { (general elementary) } \\
3 \text { (upper sec. or voc.) } \\
4 \text { (upper sec. and voc.) } \\
5 \text { (higher vocational) } \\
6 \text { (higher education) }\end{array}$ & $\begin{array}{c}0.98 \% \\
13.06 \% \\
85.95 \% \\
- \\
- \\
-\end{array}$ & $\begin{array}{c}0.05 \% \\
1.19 \% \\
15.53 \% \\
10.78 \% \\
32.04 \% \\
40.41 \%\end{array}$ \\
\hline \multicolumn{3}{|l|}{ Age of mother in t-1 } & \multicolumn{3}{|l|}{ Age of partner in t-1 } \\
\hline $\begin{array}{l}<=20 \\
21-24 \\
25-28 \\
29-32 \\
33-36 \\
37-40 \\
41-44 \\
45-49 \\
>=50\end{array}$ & $\begin{array}{c}- \\
- \\
21.79 \% \\
28.04 \% \\
24.09 \% \\
26.08 \% \\
- \\
- \\
-\end{array}$ & $\begin{array}{c}- \\
- \\
16.62 \% \\
31.99 \% \\
28.38 \% \\
23.00 \% \\
- \\
- \\
-\end{array}$ & $\begin{array}{l}<=20 \\
21-24 \\
25-28 \\
29-32 \\
33-36 \\
37-40 \\
41-44 \\
45-49 \\
>=50\end{array}$ & $\begin{array}{c}0.04 \% \\
0.98 \% \\
10.39 \% \\
22.52 \% \\
23.85 \% \\
19.85 \% \\
13.97 \% \\
5.67 \% \\
2.74 \%\end{array}$ & $\begin{array}{c}0.01 \% \\
0.33 \% \\
7.32 \% \\
24.23 \% \\
27.63 \% \\
20.60 \% \\
12.27 \% \\
5.07 \% \\
2.52 \%\end{array}$ \\
\hline \multicolumn{3}{|l|}{ State of residence } & \multicolumn{3}{|l|}{ Time since last birth in $t-1$} \\
\hline $\begin{array}{l}\text { Schleswig-Holstein } \\
\text { Hamburg } \\
\text { Niedersachsen } \\
\text { Bremen } \\
\text { Nordrhein-Westfalen } \\
\text { Hessen } \\
\text { Rheinland-Pfalz } \\
\text { Baden-Wuertemberg } \\
\text { Bayern } \\
\text { Saarland } \\
\text { Berlin }\end{array}$ & $\begin{array}{c}4.31 \% \\
1.72 \% \\
12.39 \% \\
0.77 \% \\
27.40 \% \\
8.27 \% \\
7.36 \% \\
12.80 \% \\
20.49 \% \\
2.26 \% \\
2.23 \%\end{array}$ & $\begin{array}{c}4.55 \% \\
2.03 \% \\
10.93 \% \\
0.79 \% \\
26.15 \% \\
10.35 \% \\
6.27 \% \\
15.86 \% \\
18.70 \% \\
1.75 \% \\
2.61 \%\end{array}$ & $\begin{array}{r}0 \text { years } \\
1 \text { year } \\
2-3 \text { years } \\
4-5 \text { years } \\
6-7 \text { years } \\
8-10 \text { years } \\
\text { Over } 10 \text { years }\end{array}$ & $\begin{array}{c}9.99 \% \\
10.65 \% \\
16.74 \% \\
12.90 \% \\
10.33 \% \\
13.17 \% \\
26.22 \%\end{array}$ & $\begin{array}{c}17.27 \% \\
16.14 \% \\
20.62 \% \\
11.65 \% \\
9.12 \% \\
10.34 \% \\
14.87 \%\end{array}$ \\
\hline $\begin{array}{r}\text { Community/City size in t } \\
<20 \\
20-100 \\
100-500 \\
>500\end{array}$ & $\begin{array}{l}\text { ands } \\
47.21 \% \\
27.39 \% \\
14.42 \% \\
10.98 \%\end{array}$ & $\begin{array}{l}42.84 \% \\
27.90 \% \\
16.46 \% \\
12.79 \%\end{array}$ & & & \\
\hline
\end{tabular}

Source: Own calculations based on the Mikrozensus waves 1995, 1996, 1998, and 1999. 
Table A.4 Descriptive statistics of explanatory variables: couples without children; broad definition of educational groups; SOEP

\begin{tabular}{|c|c|c|c|c|c|}
\hline & Low & High & & Low & High \\
\hline $\mathbf{N}$ & 573 & 651 & & & \\
\hline Married in $\mathbf{t}$ & $56.72 \%$ & $53.92 \%$ & & & \\
\hline \multicolumn{3}{|l|}{ ISCED mother } & \multicolumn{3}{|l|}{ ISCED partner } \\
\hline 1 (inadequately) & $7.15 \%$ & $1.09 \%$ & 1 (inadequately) & $7.16 \%$ & $1.84 \%$ \\
\hline 2 (general elementary) & $13.44 \%$ & $5.07 \%$ & 2 (general elementary) & $20.24 \%$ & $4.45 \%$ \\
\hline 3 (upper sec. or voc.) & $79.41 \%$ & $29.49 \%$ & 3 (upper sec. or voc.) & $72.60 \%$ & $16.28 \%$ \\
\hline 4 (upper sec. and voc.) & - & $14.59 \%$ & 4 (upper sec. and voc.) & - & $14.44 \%$ \\
\hline 5 (higher vocational) & - & $20.89 \%$ & 5 (higher vocational) & - & $16.59 \%$ \\
\hline 6 (higher education) & - & $28.88 \%$ & 6 (higher education) & - & $46.39 \%$ \\
\hline \multicolumn{3}{|l|}{ Age of mother in $t$} & \multicolumn{3}{|l|}{ Age of partner in $t$} \\
\hline$<=24$ & - & - & $<=24$ & $3.49 \%$ & $1.38 \%$ \\
\hline $25-28$ & $46.77 \%$ & $38.40 \%$ & $25-28$ & $23.56 \%$ & $17.97 \%$ \\
\hline $29-32$ & $25.65 \%$ & $35.18 \%$ & $29-32$ & $27.57 \%$ & $33.79 \%$ \\
\hline $33-36$ & $13.61 \%$ & $16.44 \%$ & $33-36$ & $19.72 \%$ & $20.12 \%$ \\
\hline $37-40$ & $13.96 \%$ & $9.98 \%$ & $37-40$ & $10.82 \%$ & $9.68 \%$ \\
\hline $41-44$ & - & - & $41-44$ & $8.20 \%$ & $7.53 \%$ \\
\hline $45-49$ & - & - & $45-49$ & $3.84 \%$ & $4.92 \%$ \\
\hline$>=50$ & - & - & $>=50$ & $2.79 \%$ & $4.61 \%$ \\
\hline \multicolumn{6}{|l|}{ State of residence } \\
\hline Schleswig-Holstein & $5.06 \%$ & $4.45 \%$ & & & \\
\hline Hamburg & $0.87 \%$ & $2.30 \%$ & & & \\
\hline Niedersachsen & $17.98 \%$ & $15.67 \%$ & & & \\
\hline Bremen & $1.57 \%$ & $1.69 \%$ & & & \\
\hline Nordrhein-Westfalen & $23.56 \%$ & $30.72 \%$ & & & \\
\hline Hessen & $7.50 \%$ & $9.37 \%$ & & & \\
\hline Rheinl.-Pf.+Saarland & $11.87 \%$ & $6.61 \%$ & & & \\
\hline Baden-Wuertemberg & $12.04 \%$ & $13.67 \%$ & & & \\
\hline Bayern & $19.55 \%$ & $15.51 \%$ & & & \\
\hline
\end{tabular}

Source: Own calculations based on the SOEP waves 1992-1994 and 1996-1998. 
Table A.5 Descriptive statistics of explanatory variables: couples with one child; broad definition of educational groups; SOEP

\begin{tabular}{|c|c|c|c|c|c|}
\hline & Low & High & & Low & High \\
\hline $\mathbf{N}$ & 832 & 582 & & & \\
\hline Married in $\mathbf{t}$ & $90.38 \%$ & $89.86 \%$ & & & \\
\hline \multicolumn{3}{|l|}{ ISCED mother } & \multicolumn{3}{|l|}{ ISCED partner } \\
\hline 1 (inadequately) & $2.88 \%$ & $2.92 \%$ & 1 (inadequately) & $3.12 \%$ & $1.04 \%$ \\
\hline 2 (general elementary) & $18.39 \%$ & $9.62 \%$ & 2 (general elementary) & $15.63 \%$ & $5.50 \%$ \\
\hline 3 (upper sec. or voc.) & $78.73 \%$ & $30.58 \%$ & 3 (upper sec. or voc.) & $81.25 \%$ & $15.29 \%$ \\
\hline 4 (upper sec. and voc.) & - & $14.09 \%$ & 4 (upper sec. and voc.) & - & $11.34 \%$ \\
\hline 5 (higher vocational) & - & $24.57 \%$ & 5 (higher vocational) & - & $31.96 \%$ \\
\hline 6 (higher education) & - & $18.21 \%$ & 6 (higher education) & - & $34.88 \%$ \\
\hline \multicolumn{3}{|l|}{ Age of mother in $t$} & \multicolumn{3}{|l|}{ Age of partner in $t$} \\
\hline$<=24$ & - & - & $<=24$ & $1.08 \%$ & $1.03 \%$ \\
\hline $25-28$ & $26.80 \%$ & $20.10 \%$ & $25-28$ & $13.58 \%$ & $8.25 \%$ \\
\hline $29-32$ & $29.69 \%$ & $34.19 \%$ & $29-32$ & $24.64 \%$ & $27.32 \%$ \\
\hline $33-36$ & $25.36 \%$ & $26.46 \%$ & $33-36$ & $21.51 \%$ & $28.69 \%$ \\
\hline $37-40$ & $18.15 \%$ & $19.24 \%$ & $37-40$ & $20.19 \%$ & $19.07 \%$ \\
\hline $41-44$ & - & - & $41-44$ & $10.82 \%$ & $9.28 \%$ \\
\hline $45-49$ & - & - & $45-49$ & $6.01 \%$ & $3.95 \%$ \\
\hline$>=50$ & - & - & $>=50$ & $2.16 \%$ & $2.41 \%$ \\
\hline \multicolumn{3}{|l|}{ State of residence } & \multicolumn{3}{|l|}{ Time since last birth in $t$} \\
\hline Schleswig-Holstein & $3.85 \%$ & $3.26 \%$ & 0 years & $10.10 \%$ & $16.32 \%$ \\
\hline Hamburg & $0.96 \%$ & $1.89 \%$ & 1 year & $10.94 \%$ & $18.90 \%$ \\
\hline Niedersachsen & $13.94 \%$ & $12.89 \%$ & $2-3$ years & $16.95 \%$ & $22.16 \%$ \\
\hline Bremen & $0.84 \%$ & $0.17 \%$ & $4-5$ years & $10.82 \%$ & $11.86 \%$ \\
\hline Nordrhein-Westfalen & $27.52 \%$ & $32.47 \%$ & 6-7 years & $11.06 \%$ & $9.28 \%$ \\
\hline Hessen & $6.49 \%$ & $7.39 \%$ & $8-10$ years & $14.90 \%$ & $11.17 \%$ \\
\hline Rheinland-Pfalz & $12.50 \%$ & $8.42 \%$ & Over 10 years & $25.24 \%$ & $10.31 \%$ \\
\hline Baden-Wuertemberg & $15.99 \%$ & $15.46 \%$ & & & \\
\hline Bayern & $17.91 \%$ & $18.04 \%$ & & & \\
\hline
\end{tabular}

Source: Own calculations based on the SOEP waves 1992-1994 and 1996-1998. 
Table A.6 Estimation results: reform effect on the propensity to have a first or second child based on SOEP data; treatment and control groups defined by household income in the highest vs. lowest quartile

\begin{tabular}{|c|c|c|c|c|}
\hline & \multicolumn{2}{|c|}{$\begin{array}{c}\text { High vs. Low Income } \\
\text { No Children }\end{array}$} & \multicolumn{2}{|c|}{$\begin{array}{l}\text { High vs. Low Income } \\
\text { One Child }\end{array}$} \\
\hline & 1 & 2 & 3 & 4 \\
\hline Post Reform & $\begin{array}{l}-0.001 \\
(0.040)\end{array}$ & $\begin{array}{l}0.006 \\
(0.059)\end{array}$ & $\begin{array}{c}0.017 \\
(0.036)\end{array}$ & $\begin{array}{c}0.050 \\
(0.051)\end{array}$ \\
\hline Low Income & $\begin{array}{l}-0.009 \\
(0.041)\end{array}$ & $\begin{array}{c}0.004 \\
(0.049)\end{array}$ & - & - \\
\hline Low Inc. *Post Reform & $\begin{array}{l}-0.072 \\
(0.050)\end{array}$ & $\begin{array}{l}-0.058 \\
(0.052)\end{array}$ & - & - \\
\hline High Income & - & - & $\begin{array}{c}-0.065^{* *} \\
(0.031)\end{array}$ & $\begin{array}{l}-0.047 \\
(0.034)\end{array}$ \\
\hline High Inc.*Post Reform & - & - & $\begin{array}{c}0.029 \\
(0.046)\end{array}$ & $\begin{array}{c}0.016 \\
(0.046)\end{array}$ \\
\hline Additional Controls & No & Yes & No & Yes \\
\hline $\mathrm{N}$ & 584 & 584 & 668 & 668 \\
\hline $\mathrm{R}^{2}$ & 0.0120 & 0.1377 & 0.0084 & 0.1122 \\
\hline
\end{tabular}

Notes: Robust S.E., clustered by person, in parentheses, ${ }^{*} \mathrm{p}<0.10, * * \mathrm{p}<0.05, * * * \mathrm{p}<0.010$. The dependent variable in all models is birth in $t+1$. Its mean is 0.1055 for couples without children and 0.1065 for couples with one child. "Low Income" and "High Income" are dummies indicating that a family is in the lowest or highest income quartile in the sample. The middle quartiles are not part of the sample. The additional controls are sets of dummies for mother's and partner's age in steps of 4 years, marital status, federal state, month and year of observation. Column 4 additionally contains a set of categorical indicators of birth spacing.

Source: See Table 5. 
Table A.7 Estimation results: reform effect on the propensity to have a first or second child based on Mikrozensus data; treatment and control groups defined by treatment kink for second births

\begin{tabular}{|c|c|c|c|c|}
\hline & \multicolumn{2}{|c|}{$\begin{array}{l}\text { High vs. Low Income } \\
\text { No Children }\end{array}$} & \multicolumn{2}{|c|}{$\begin{array}{c}\text { High vs. Low Income } \\
\text { One Child }\end{array}$} \\
\hline & 1 & 2 & 3 & 4 \\
\hline Post Reform & $\begin{array}{c}0.004 \\
(0.003)\end{array}$ & $\begin{array}{c}0.002 \\
(0.005)\end{array}$ & $\begin{array}{l}-0.002 \\
(0.007)\end{array}$ & $\begin{array}{c}0.002 \\
(0.007)\end{array}$ \\
\hline Low Income & $\begin{array}{l}0.125^{* * *} \\
(0.007)\end{array}$ & $\begin{array}{c}0.133^{* * *} \\
(0.007)\end{array}$ & - & - \\
\hline Low Inc.*Post Reform & $\begin{array}{l}-0.011 \\
(0.010)\end{array}$ & $\begin{array}{l}-0.008 \\
(0.010)\end{array}$ & - & - \\
\hline High Income & - & - & $\begin{array}{c}-0.023 * * * \\
(0.005)\end{array}$ & $\begin{array}{c}-0.014 * * * \\
(0.005)\end{array}$ \\
\hline High Inc.*Post Reform & - & - & $\begin{array}{c}0.016^{* *} \\
(0.008)\end{array}$ & $\begin{array}{c}0.010 \\
(0.007)\end{array}$ \\
\hline Additional Controls & No & Yes & No & Yes \\
\hline $\mathrm{N}$ & 34,977 & 34,977 & 31,985 & 31,985 \\
\hline $\mathrm{R}^{2}$ & 0.0255 & 0.0772 & 0.0008 & 0.1104 \\
\hline
\end{tabular}

Notes: Robust S.E. in parentheses, ${ }^{*} \mathrm{p}<0.10,{ }^{* *} \mathrm{p}<0.05, * * * \mathrm{p}<0.010$. The dependent variable in all models is birth in $t$. Its mean is 0.1048 for couples without children and 0.1144 for couples with one child. "Low Income" and "High Income" are dummies indicating that net family income is below or above $43.000 \mathrm{DM}$ per year. This value is an approximations of net income which corresponds to a gross income of $63.000 \mathrm{DM}$, which is the relevant kink in the budget constraint. The additional controls are sets of dummies for mother's and partner's lagged age in steps of 4 years, lagged marital status, federal state, year of observation and city size. Column 4 additionally considers a set of categorical indicators of birth spacing.

Source: See Table 3. 
Table A.8 Estimation results: reform effect on the propensity to have a first or second child based on SOEP data; treatment and control groups defined by treatment kink for second births

\begin{tabular}{|c|c|c|c|c|}
\hline & \multicolumn{2}{|c|}{$\begin{array}{c}\text { High vs. Low Income } \\
\text { No Children }\end{array}$} & \multicolumn{2}{|c|}{$\begin{array}{c}\text { High vs. Low Income } \\
\text { One Child }\end{array}$} \\
\hline & 1 & 2 & 3 & 4 \\
\hline Post Reform & $\begin{array}{c}0.003 \\
(0.022)\end{array}$ & $\begin{array}{c}0.046 \\
(0.041)\end{array}$ & $\begin{array}{c}0.026 \\
(0.027)\end{array}$ & $\begin{array}{c}0.037 \\
(0.035)\end{array}$ \\
\hline Low Income & $\begin{array}{l}-0.015 \\
(0.031)\end{array}$ & $\begin{array}{l}0.004 \\
(0.032)\end{array}$ & - & - \\
\hline Low Inc.*Post Reform & $\begin{array}{l}-0.069^{*} \\
(0.039)\end{array}$ & $\begin{array}{c}-0.085^{* *} \\
(0.040)\end{array}$ & - & - \\
\hline High Income & - & - & $\begin{array}{l}-0.008 \\
(0.025)\end{array}$ & $\begin{array}{c}0.011 \\
(0.026)\end{array}$ \\
\hline High Inc. ${ }^{*}$ Post Reform & - & - & $\begin{array}{l}-0.009 \\
(0.035)\end{array}$ & $\begin{array}{l}-0.025 \\
(0.035)\end{array}$ \\
\hline Additional Controls & No & Yes & No & Yes \\
\hline $\mathrm{N}$ & 1,157 & 1,157 & 1,312 & 1,312 \\
\hline $\mathrm{R}^{2}$ & 0.0065 & 0.1006 & 0.0014 & 0.0966 \\
\hline
\end{tabular}

Notes: Robust S.E. clustered by person in parentheses, $* \mathrm{p}<0.10, * * \mathrm{p}<0.05, * * * \mathrm{p}<0.010$. The dependent variable in all models is birth in $t$. Its mean is 0.1165 for couples without children and 0.1187 for couples with one child. "Low Income" and "High Income" are dummies indicating that gross family income is below or above $63.000 \mathrm{DM}$ per year. The additional controls are sets of dummies for mother's and partner's age in steps of 4 years, marital status, federal state, month and year of observation. Column 4 additionally contains a set of categorical indicators of birth spacing.

Source: See Table 5. 
Table A.9 Estimation results: reform effect on the propensity to have a first child based on Mikrozensus data - married couples only

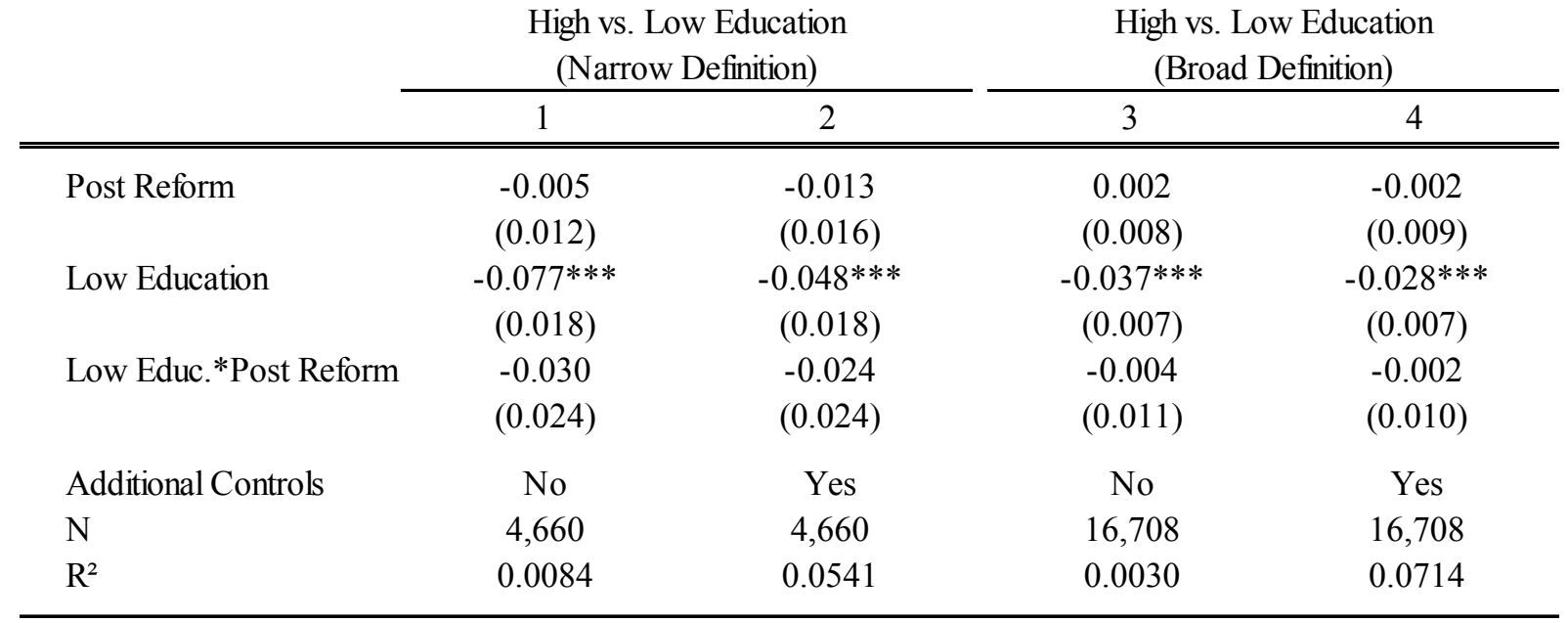

Notes: See Table 3. The mean of the dependent variable is now 0.1624 in the narrow definition and 0.1430 in the broad definition.

Source: See Table 3.

Table A.10 Estimation results: reform effect on the propensity to have a second child based on Mikrozensus data - married couples only

\begin{tabular}{lccccc} 
& \multicolumn{2}{c}{$\begin{array}{c}\text { High vs. Low Education } \\
\text { (Narrow Definition) }\end{array}$} & & \multicolumn{2}{c}{$\begin{array}{c}\text { High vs. Low Education } \\
\text { (Broad Definition) }\end{array}$} \\
\cline { 2 - 3 } \cline { 5 - 6 } & \multicolumn{2}{c}{1} & 2 & 3 & 4 \\
\hline \hline Post Reform & -0.024 & $-0.049^{* * *}$ & & 0.003 & -0.001 \\
& $(0.015)$ & $(0.018)$ & & $(0.005)$ & $(0.006)$ \\
High Education & $0.074^{* * *}$ & $0.029^{* *}$ & & $0.044^{* * *}$ & $0.032^{* * *}$ \\
& $(0.014)$ & $(0.014)$ & & $(0.006)$ & $(0.005)$ \\
High Educ.*Post Reform & $0.032^{*}$ & $0.034^{*}$ & & 0.011 & $0.014^{*}$ \\
& $(0.019)$ & $(0.019)$ & & $(0.008)$ & $(0.008)$ \\
Additional Controls & No & Yes & & No & Yes \\
$\mathrm{N}$ & 5,711 & 5,711 & & 27,787 & 27,787 \\
$\mathrm{R}^{2}$ & 0.0111 & 0.1356 & & 0.0059 & 0.1157 \\
\hline
\end{tabular}

Notes: See Table 4. The mean of the dependent variable is now 0.1567 in the narrow definition and 0.1190 in the broad definition.

Source: See Table 3. 
Table A.11 Estimation results: reform effect on the propensity to have first or second child based on Mikrozensus data with state specific linear and quadratic trends

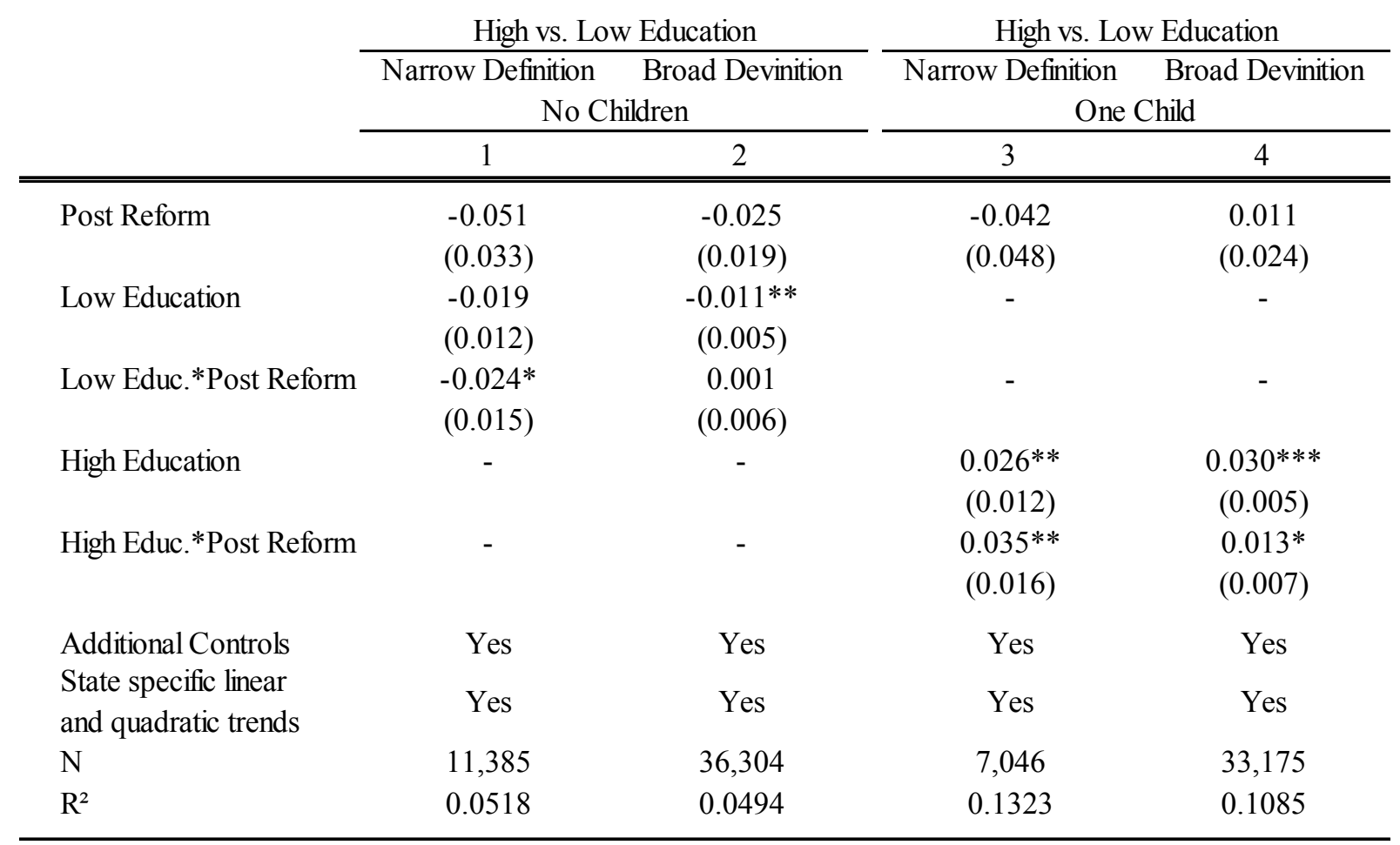

Notes: See Tables 3 and 4 . The only difference are the added state specific linear and quadratic time trends and the reduction in columns.

Source: See Table 3. 
Table A.12 Estimation results: reform effect on maternal age at second birth (timing) based on Mikrozensus data

\begin{tabular}{lcccccc} 
& \multicolumn{2}{c}{$\begin{array}{c}\text { High vs. Low Education } \\
\text { (Narrow Definition) }\end{array}$} & & \multicolumn{2}{c}{$\begin{array}{c}\text { High vs. Low Education } \\
\text { (Broad Definition) }\end{array}$} \\
\cline { 2 - 3 } \cline { 5 - 6 } & \multicolumn{2}{c}{1} & 2 & & 3 & 4 \\
\hline \hline \multirow{2}{*}{ Post Reform } & -0.555 & 0.202 & & $0.342^{* *}$ & $0.663^{* * *}$ \\
& $(0.548)$ & $(0.581)$ & & $(0.145)$ & $(0.181)$ \\
High Education & $1.676^{* * *}$ & $1.696^{* * *}$ & & $1.112^{* * *}$ & $1.094^{* * *}$ \\
& $(0.401)$ & $(0.394)$ & & $(0.148)$ & $(0.149)$ \\
High Educ.*Post Reform & $1.282^{* *}$ & $1.213^{* *}$ & & $0.406^{* *}$ & $0.374^{*}$ \\
& $(0.587)$ & $(0.583)$ & & $(0.207)$ & $(0.207)$ \\
Additional Controls & $\mathrm{No}$ & Yes & & No & Yes \\
$\mathrm{N}$ & 1,031 & 1,031 & & 3,807 & 3,807 \\
$\mathrm{R}^{2}$ & 0.0716 & 0.1023 & & 0.0500 & 0.0604 \\
\hline
\end{tabular}

Notes: Robust S.E. in parentheses, ${ }^{*} \mathrm{p}<0.10, * * \mathrm{p}<0.05, * * * \mathrm{p}<0.010$. The dependent variable in all models is mother's age at childbirth. Its mean is 32.23 in the narrow definition and 31.25 in the broad definition. The samples are relatively small because only the observations of women who gave birth in period $t$ are included. The additional controls are sets of dummies for mother's and partner's lagged age in steps of 4 years, lagged marital status, federal state, year of observation, and city size.

Source: See Table 3.

Table A.13 Estimation results: reform effect on time between first and second birth (spacing) based on Mikrozensus data

\begin{tabular}{|c|c|c|c|c|}
\hline & \multicolumn{2}{|c|}{$\begin{array}{l}\text { High vs. Low Education } \\
\text { (Narrow Definition) }\end{array}$} & \multicolumn{2}{|c|}{$\begin{array}{l}\text { High vs. Low Education } \\
\text { (Broad Definition) }\end{array}$} \\
\hline & 1 & 2 & 3 & 4 \\
\hline Post Reform & $\begin{array}{l}-0.555 \\
(0.548)\end{array}$ & $\begin{array}{c}0.202 \\
(0.581)\end{array}$ & $\begin{array}{c}0.342^{* *} \\
(0.145)\end{array}$ & $\begin{array}{c}0.663 * * * \\
(0.181)\end{array}$ \\
\hline High Education & $\begin{array}{c}1.676^{* * *} \\
(0.401)\end{array}$ & $\begin{array}{c}1.696 * * * \\
(0.394)\end{array}$ & $\begin{array}{c}1.112 * * * \\
(0.148)\end{array}$ & $\begin{array}{c}1.094 * * * \\
(0.149)\end{array}$ \\
\hline High Educ. *Post Reform & $\begin{array}{l}1.282 * * \\
(0.587)\end{array}$ & $\begin{array}{l}1.213 * * \\
(0.583)\end{array}$ & $\begin{array}{l}0.406^{* *} \\
(0.207)\end{array}$ & $\begin{array}{l}0.374 * \\
(0.207)\end{array}$ \\
\hline Additional Controls & No & Yes & No & Yes \\
\hline $\mathrm{N}$ & 1,031 & 1,031 & 3,807 & 3,807 \\
\hline $\mathrm{R}^{2}$ & 0.0716 & 0.1023 & 0.0500 & 0.0604 \\
\hline
\end{tabular}

Notes: Robust S.E. in parentheses, ${ }^{*} \mathrm{p}<0.10, * * \mathrm{p}<0.05, * * * \mathrm{p}<0.010$. The dependent variable in all models is time since last birth, which is measured in years. Its mean is 3.45 in the narrow definition and 3.87 in the broad definition. The samples are relatively small because only the observations of women who gave birth in period $t$ are included. The additional controls are sets of dummies for mother's and partner's lagged age in steps of 4 years, lagged marital status, federal state, year of observation, and city size.

Source: See Table 3. 
Figure A.1 Absolute net transfer for the first two children

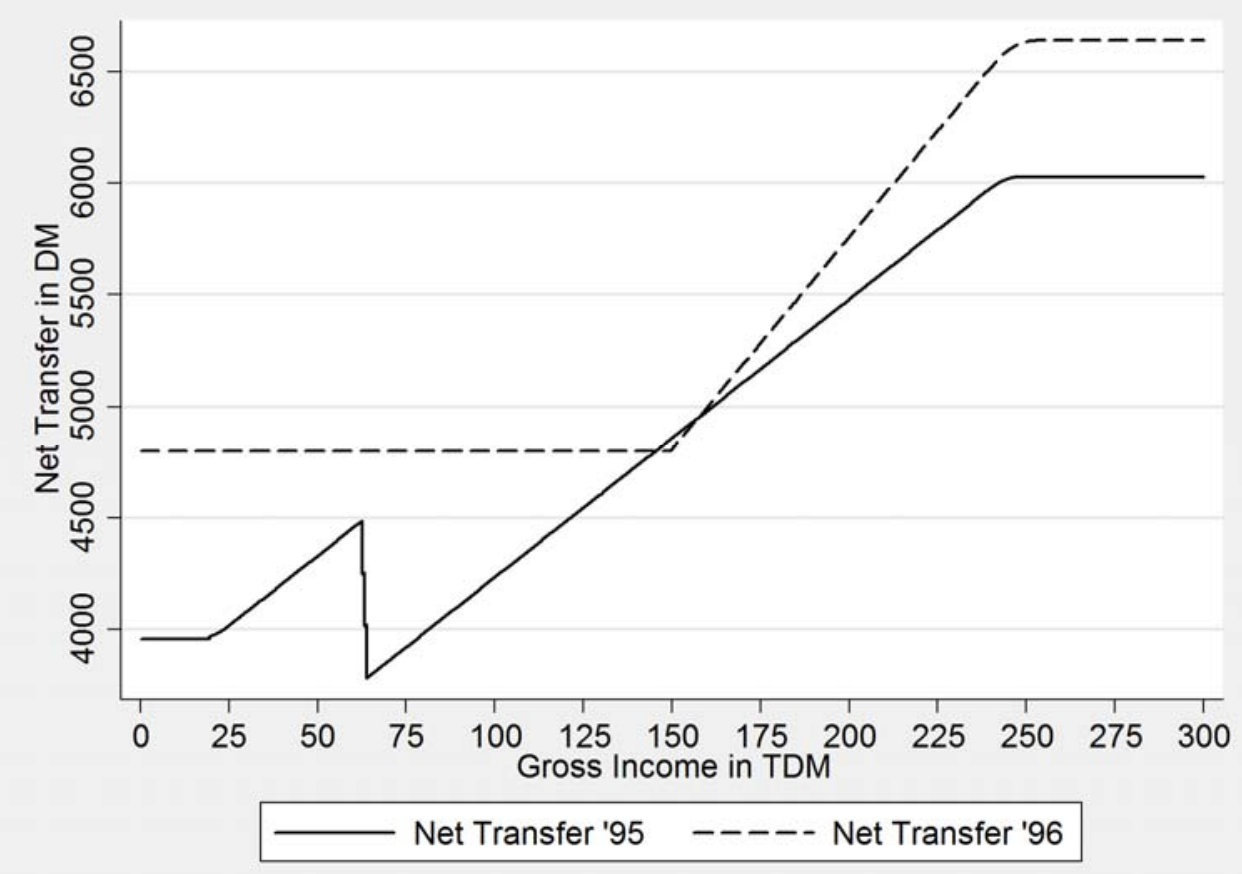

Notes: Net transfer stands for the combined amount of tax savings, child benefits, and child benefit supplements a married couple receives for their first two children together.

Source: Own calculations.

Figure A.2 Average and marginal tax rates before and after the 1995 income tax reform

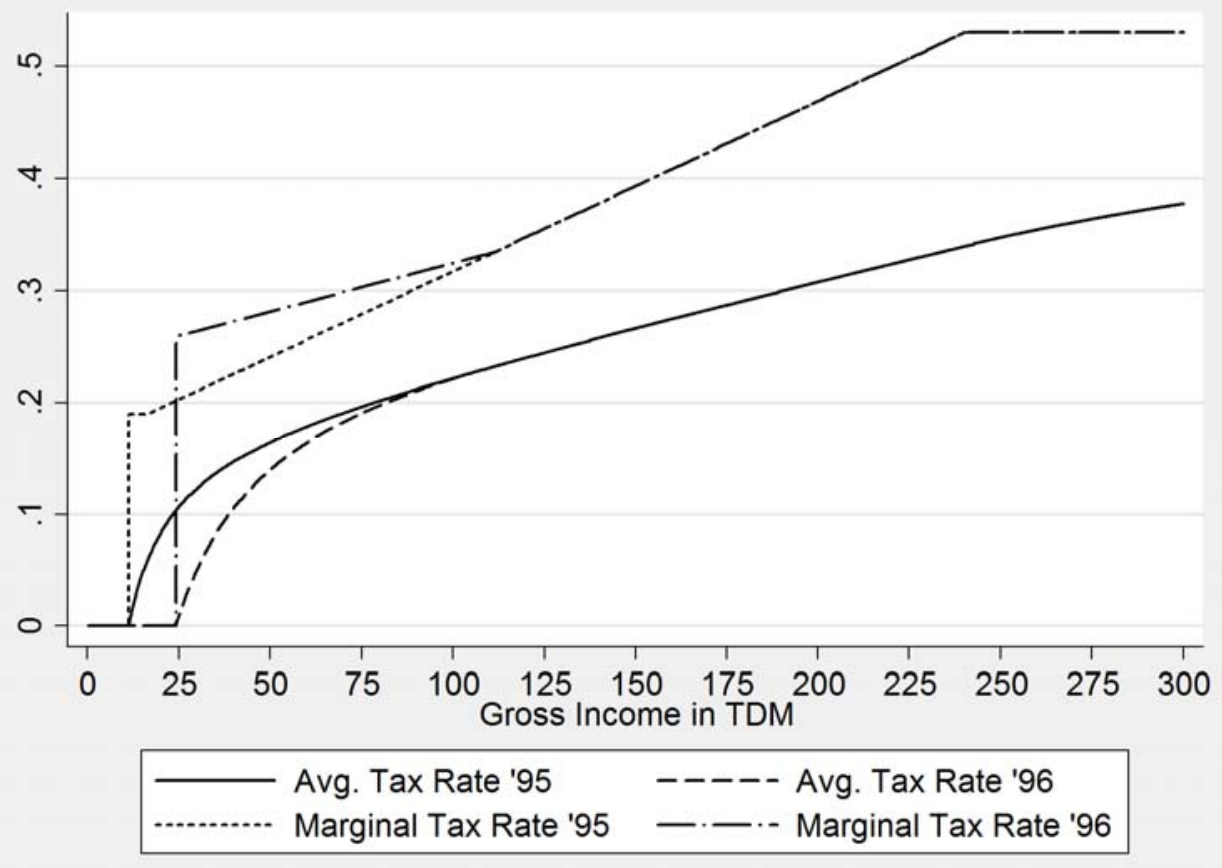

Source: Own calculations based on Lüdecke and Werding (1996). 
Figure A.3 Distribution of household net income and income-specific birthrates by parity

\section{A.3.1 Families without children}

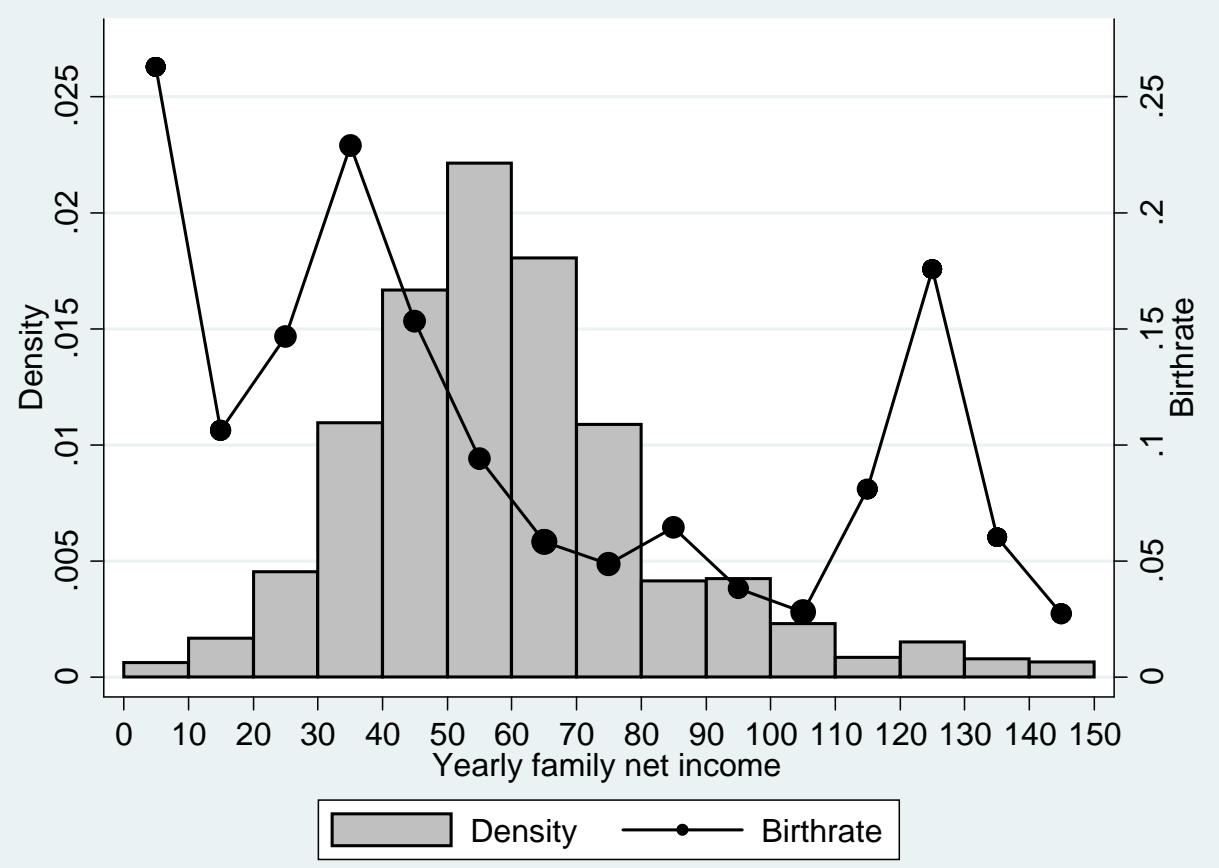

\section{A.3.2 Families with one child}

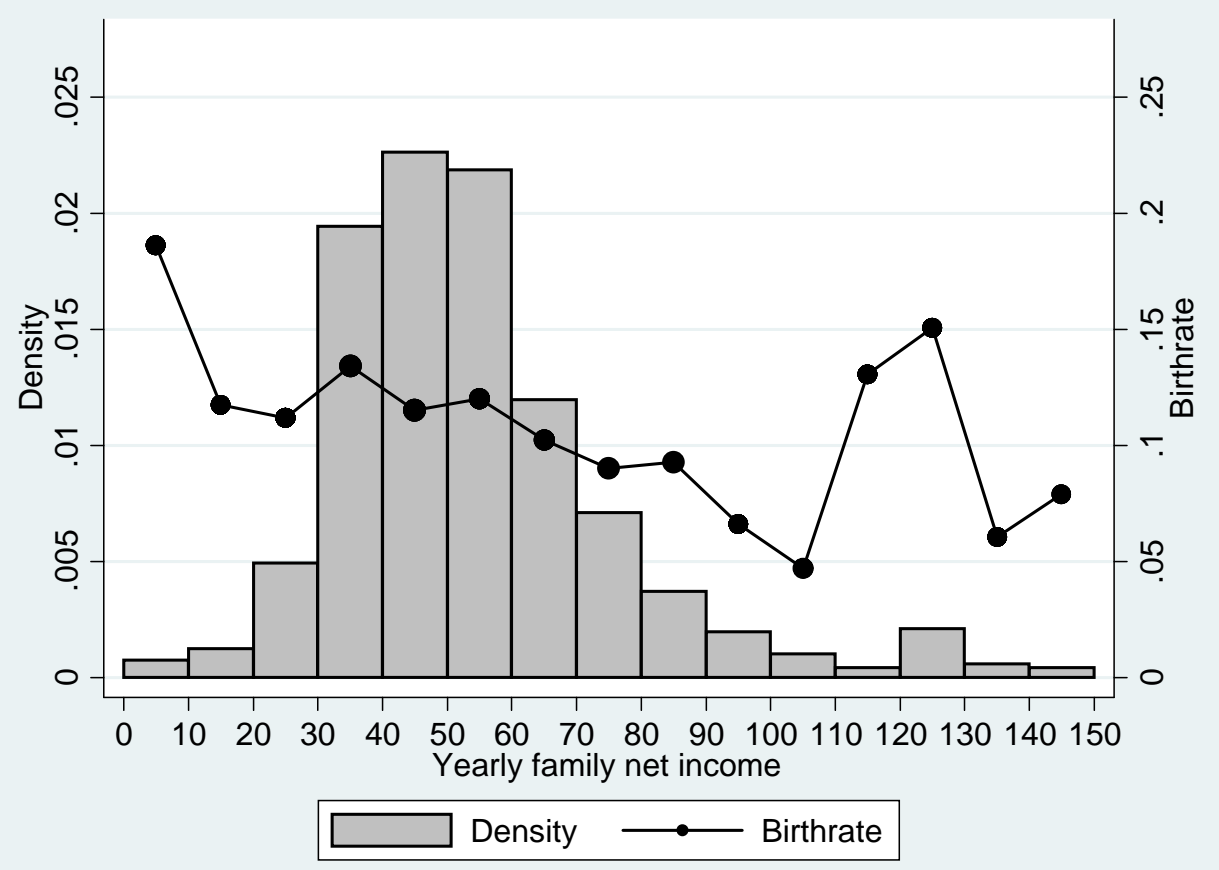

Source: Own calculations based on the Mikrozensus waves 1995, 1996, 1998, and 1999. Unfortunately, the data do not provide information on household annual gross incomes. 
Figure A.4 Sampling Strategy

Figure A.4.1 Mikrozensus

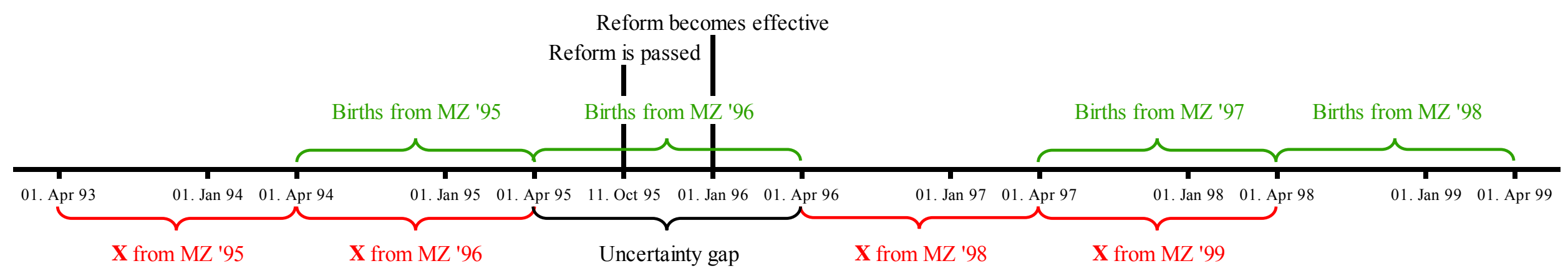

Figure A.4.2 SOEP

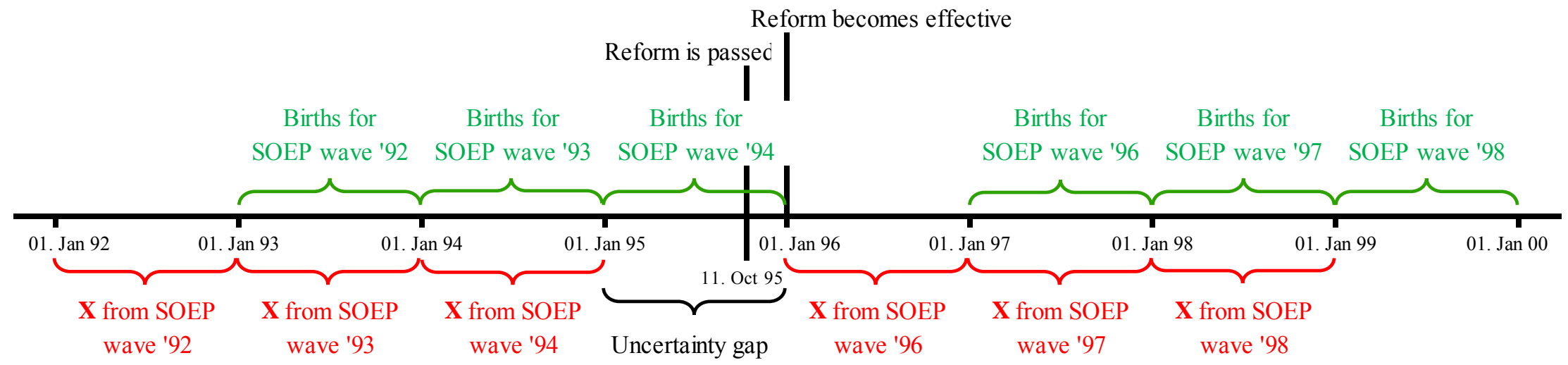

Source: Own presentation. 


\section{Appendix B - Evidence on third births}

The reform of child benefits for third births replaced a highly nonlinear benefit-by-income mapping:

\section{Figure B.1 Absolute net transfer for a third child}

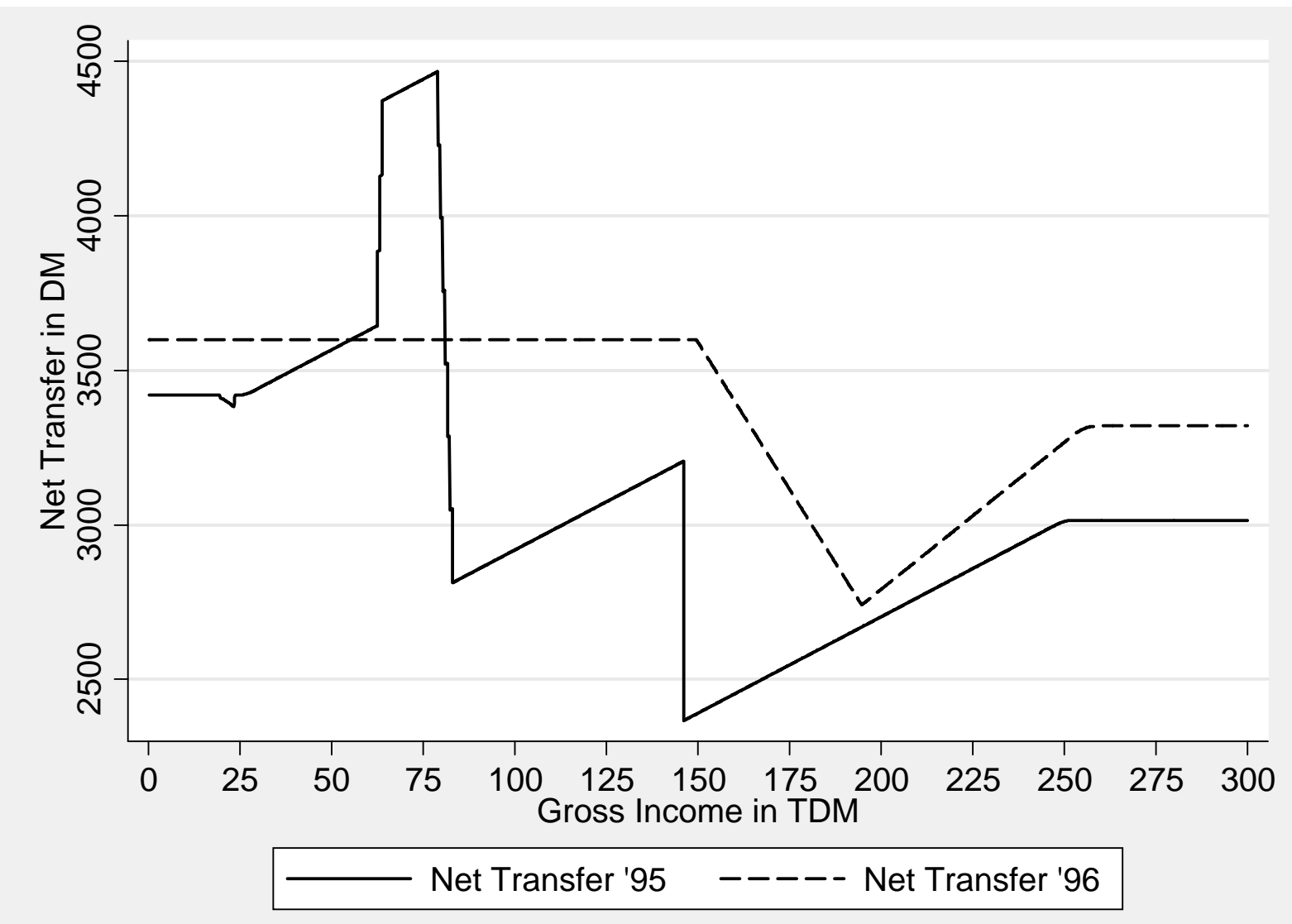

We expect an increase in third child fertility particularly for high income households. The incentives in a small segment of the gross household income distribution (65-80.000 DM) decline substantially and for the lowest income households the reform generated only a small change.

Table B.1 shows the Mikrozensus based results when applying the baseline estimation strategy i.e. separating treatment and control groups based on educational attainment. Overall, there is no significant reform effect and in the treatment group of the highly educated we even find a significant negative coefficient estimate which suggests a decline in fertility for this group. Table B.2 shows the estimation results based on the SOEP data. While insignificant, the treatment effect estimates are again negative.

As these effects are the opposite of what was hypothesized we investigated the underlying income distribution for households with two children already in the treatment (high education) and control group (low education) for both datasets. Figures B.2.1-B.3.2 describe the results. Clearly, the income distributions particularly based on the broad definitions of treatment and control groups are not very distinct. As this may generate a measurement error in our estimations we replaced the education based approach by directly using household incomes. First, we inspect the fertility response of two-child-households in the bottom and top income 
quartiles and then we separately consider the group of households who lost the most due to the reform, as their third-child-fertility might have declined.

Table B.3 shows the estimates for income-quartile based regressions for two-child-households. Here, the Mikrozensus estimates of the treatment effect lose statistical significance. In Table B.4 we explicitly consider households as treatment group who are located in the critical range between 55.400 DM and 81.0000 DM gross household income (39.600-52.800 DM net household income) where we expect to see a drop in fertility after the reform. Interestingly, this specification confirms the negative expected fertility effect based on the SOEP data. While the sample size of the SOEP sample is smaller, it may be more precise in depicting the appropriate income range, because it measures income in gross amounts. The net incomes provided by the Mikrozensus might be less appropriate, because they are only proxies for the corresponding gross earnings and also the limits in net amounts for which the reform has a positive or negative effect are approximated.

Table B.1 Estimation results: reform effect on the propensity to have a third child based on Mikrozensus data

\begin{tabular}{lccccc} 
& \multicolumn{2}{c}{$\begin{array}{c}\text { High vs. Low Education } \\
\text { (Narrow Definition) }\end{array}$} & & \multicolumn{2}{c}{$\begin{array}{c}\text { High vs. Low Education } \\
\text { (Broad Definition) }\end{array}$} \\
\cline { 2 - 3 } \cline { 5 - 6 } & 1 & 2 & & 3 & 4 \\
\hline \hline \multirow{2}{*}{ Post Reform } & -0.009 & -0.012 & & 0.001 & 0.002 \\
& $(0.008)$ & $(0.009)$ & & $(0.002)$ & $(0.003)$ \\
High Education & 0.004 & 0.004 & & $0.009^{* * *}$ & $0.010^{* * *}$ \\
& $(0.007)$ & $(0.007)$ & & $(0.002)$ & $(0.002)$ \\
High Educ.*Post Reform & -0.001 & -0.002 & & $-0.006^{*}$ & $-0.007^{* *}$ \\
& $(0.009)$ & $(0.009)$ & & $(0.003)$ & $(0.003)$ \\
Additional Controls & No & Yes & & No & Yes \\
$\mathrm{N}$ & 8,654 & 8,654 & & 41,469 & 41,469 \\
$\mathrm{R}^{2}$ & 0.0007 & 0.0249 & & 0.0004 & 0.0164 \\
\hline
\end{tabular}

Notes: See Table 3. The mean of the dependent variable is 0.0382 in the narrow definition and 0.0288 in the broad definition.

Sources: See Table 3. 
Table B.2 Estimation results: reform effect on the propensity to have a third child based on SOEP data

\begin{tabular}{lccccc} 
& \multicolumn{2}{c}{$\begin{array}{c}\text { High vs. Low Education } \\
\text { (Narrow Definition) }\end{array}$} & & \multicolumn{2}{c}{$\begin{array}{c}\text { High vs. Low Education } \\
\text { (Broad Definition) }\end{array}$} \\
\cline { 2 - 3 } \cline { 5 - 6 } & \multicolumn{1}{c}{1} & 2 & 3 & 4 \\
\hline \hline \multirow{2}{*}{ Post Reform } & -0.000 & -0.036 & & 0.003 & -0.009 \\
& $(0.000)$ & $(0.043)$ & & $(0.008)$ & $(0.013)$ \\
High Education & $0.035^{* *}$ & 0.019 & & 0.016 & $0.018^{*}$ \\
& $(0.017)$ & $(0.029)$ & & $(0.011)$ & $(0.011)$ \\
High Ed.*Post Reform & 0.017 & $0.065^{*}$ & & -0.011 & -0.008 \\
& $(0.027)$ & $(0.039)$ & & $(0.014)$ & $(0.014)$ \\
Additional Controls & No & Yes & & No & Yes \\
$\mathrm{N}$ & 296 & 296 & & 1,688 & 1,688 \\
$\mathrm{R}^{2}$ & 0.0116 & 0.2202 & & 0.0016 & 0.0442 \\
\hline
\end{tabular}

Notes: See Table 7. The mean of the dependent variable is 0.0338 in the narrow definition and 0.0120 in the broad definition.

Sources: See Table 7.

Table B.3 Estimation results: reform effect on the propensity to have a third child based on Mikrozensus and SOEP data - treatment and control groups defined by household income in the highest vs. lowest quartile

\begin{tabular}{|c|c|c|c|c|}
\hline & \multicolumn{2}{|c|}{$\begin{array}{l}\text { High vs. Low Income } \\
\text { Two Children } \\
\text { Sample: Mikrozensus }\end{array}$} & \multicolumn{2}{|c|}{$\begin{array}{c}\text { High vs. Low Income } \\
\text { Two Children } \\
\text { Sample: SOEP }\end{array}$} \\
\hline & 1 & 2 & 3 & 4 \\
\hline Post Reform & $\begin{array}{l}-0.001 \\
(0.003)\end{array}$ & $\begin{array}{c}0.002 \\
(0.004)\end{array}$ & $\begin{array}{c}0.027 \\
(0.018)\end{array}$ & $\begin{array}{c}0.010 \\
(0.018)\end{array}$ \\
\hline High Income & $\begin{array}{c}-0.008 * * \\
(0.003)\end{array}$ & $\begin{array}{c}0.000 \\
(0.003)\end{array}$ & $\begin{array}{l}-0.005 \\
(0.013)\end{array}$ & $\begin{array}{l}-0.007 \\
(0.013)\end{array}$ \\
\hline High Inc. *Post Reform & $\begin{array}{c}0.001 \\
(0.005)\end{array}$ & $\begin{array}{l}-0.001 \\
(0.005)\end{array}$ & $\begin{array}{l}-0.020 \\
(0.022)\end{array}$ & $\begin{array}{l}-0.015 \\
(0.023)\end{array}$ \\
\hline Additional Controls & No & Yes & No & Yes \\
\hline $\mathrm{N}$ & 20,951 & 20,951 & 786 & 786 \\
\hline $\mathrm{R}^{2}$ & 0.0005 & 0.0179 & 0.0058 & 0.1037 \\
\hline
\end{tabular}

Notes: Robust S.E. in parentheses, ${ }^{*} \mathrm{p}<0.10,{ }^{* *} \mathrm{p}<0.05,{ }^{* * *} \mathrm{p}<0.010$. The mean of the dependent variable in Columns 1 and 2 is 0.0279 . The mean of the dependent variable in Columns 3 and 4 is 0.023 . "Low Income" and "High Income" indicate that a family is in the lowest or highest income quartile in the sample. The middle quartiles are not part of the sample. The additional controls in Column 2 are sets of dummies for mother's and partner's lagged age in steps of 4 years, lagged marital status, federal state, year of observation, city size and a set of categorical indicators of birth spacing. Column 4 instead contains dummies for mother's and partner's age in steps of 4 years, marital status, federal state, year and month of observation and a set of categorical indicators of birth spacing.

Sources: See Table 5. 
Table B.4 Estimation results: reform effect on the propensity to have a third child based on Mikrozensus and SOEP data - treatment and control groups defined by household income within the critical range

\begin{tabular}{|c|c|c|c|c|}
\hline & \multicolumn{2}{|c|}{$\begin{array}{l}\text { High vs. Low Income } \\
\text { Two Children } \\
\text { Sample: Mikrozensus }\end{array}$} & \multicolumn{2}{|c|}{$\begin{array}{l}\text { High vs. Low Income } \\
\text { Two Children } \\
\text { Sample: SOEP }\end{array}$} \\
\hline & 1 & 2 & 3 & 4 \\
\hline Post Reform & $\begin{array}{l}-0.002 \\
(0.002)\end{array}$ & $\begin{array}{l}-0.000 \\
(0.003)\end{array}$ & $\begin{array}{c}0.010 \\
(0.009)\end{array}$ & $\begin{array}{c}0.000 \\
(0.012)\end{array}$ \\
\hline Middle Income & $\begin{array}{c}0.001 \\
(0.003)\end{array}$ & $\begin{array}{l}-0.001 \\
(0.003)\end{array}$ & $\begin{array}{c}0.008 \\
(0.011)\end{array}$ & $\begin{array}{c}0.009 \\
(0.012)\end{array}$ \\
\hline Middle Inc.*Post Reform & $\begin{array}{c}0.004 \\
(0.004)\end{array}$ & $\begin{array}{c}0.003 \\
(0.004)\end{array}$ & $\begin{array}{c}-0.029^{* *} \\
(0.014)\end{array}$ & $\begin{array}{c}-0.027^{* *} \\
(0.014)\end{array}$ \\
\hline Additional Controls & No & Yes & No & Yes \\
\hline $\mathrm{N}$ & 39,853 & 39,853 & 1,568 & 1,568 \\
\hline $\mathrm{R}^{2}$ & 0.0001 & 0.0180 & 0.0034 & 0.0564 \\
\hline
\end{tabular}

Notes: Robust S.E. in parentheses, ${ }^{*} \mathrm{p}<0.10,{ }^{* *} \mathrm{p}<0.05,{ }^{* * *} \mathrm{p}<0.010$. Columns 1 and 2 show the results for the Mikrozensus. The mean of the dependent variable is 0.029 . The variable Middle Income denotes family net incomes between 39,600 and 52,800 DM. This is the approximate net income range for which the reform lessened incentives in terms of a third child. Columns 3 and 4 show the results for the SOEP. The mean of the dependent variable is 0.019 . Here Middle income marks families with a gross income between 55,400 and 81,000 DM, which is the exact range of negatively affected incomes. The additional controls in column 2, are sets of dummies for mother's and partner's lagged age in steps of 4 years, lagged marital status, federal state, year of observation, city size and a set of categorical indicators of birth spacing. Column 4 instead contains dummies for mother's and partner's age in steps of 4 years, marital status, federal state, year and month of observation, and a set of categorical indicators of birth spacing.

Sources: See Table 5. 
Figure B.2.1 Income distribution of families with two children in treatment and control group (narrow definition) - Mikrozensus

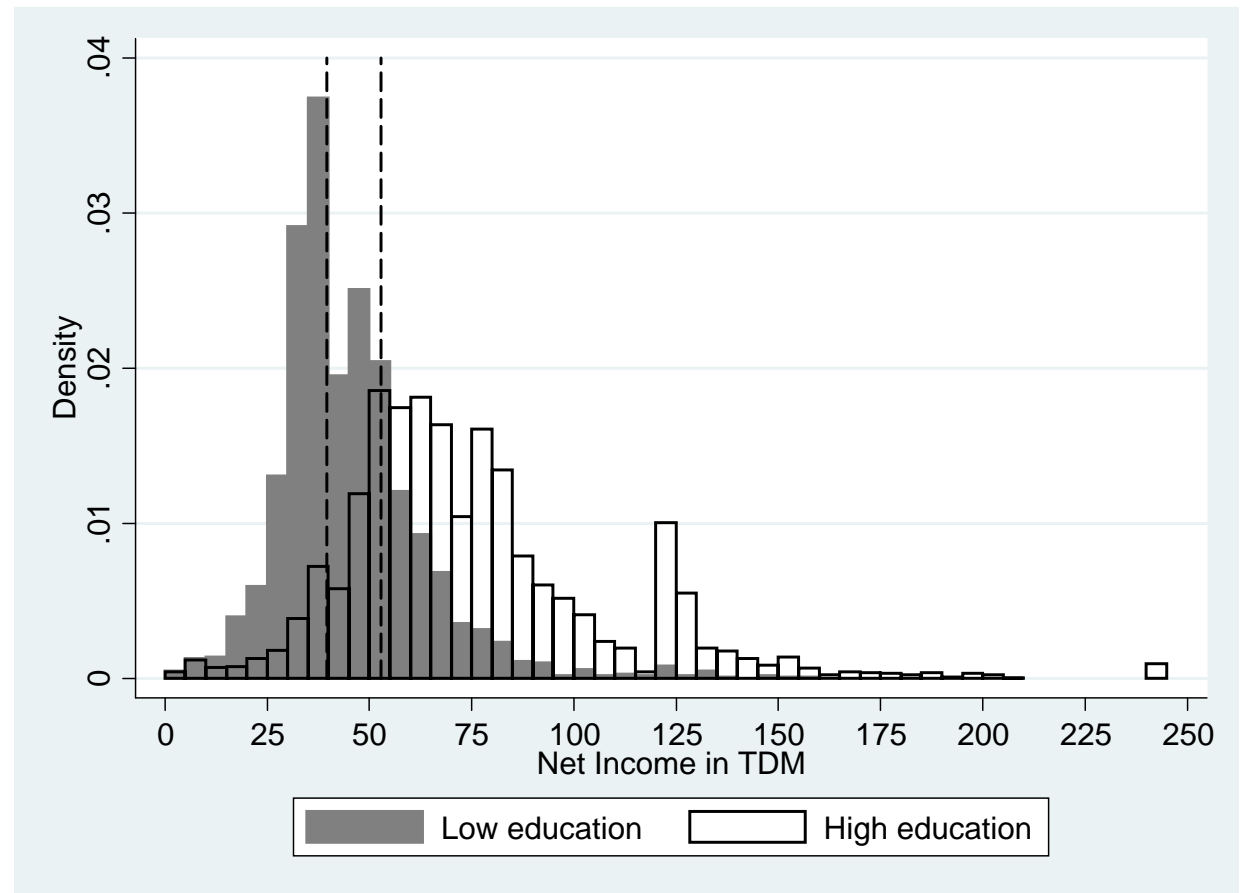

Figure B.2.2 Income distribution of families with two children in treatment and control group (broad definition) - Mikrozensus

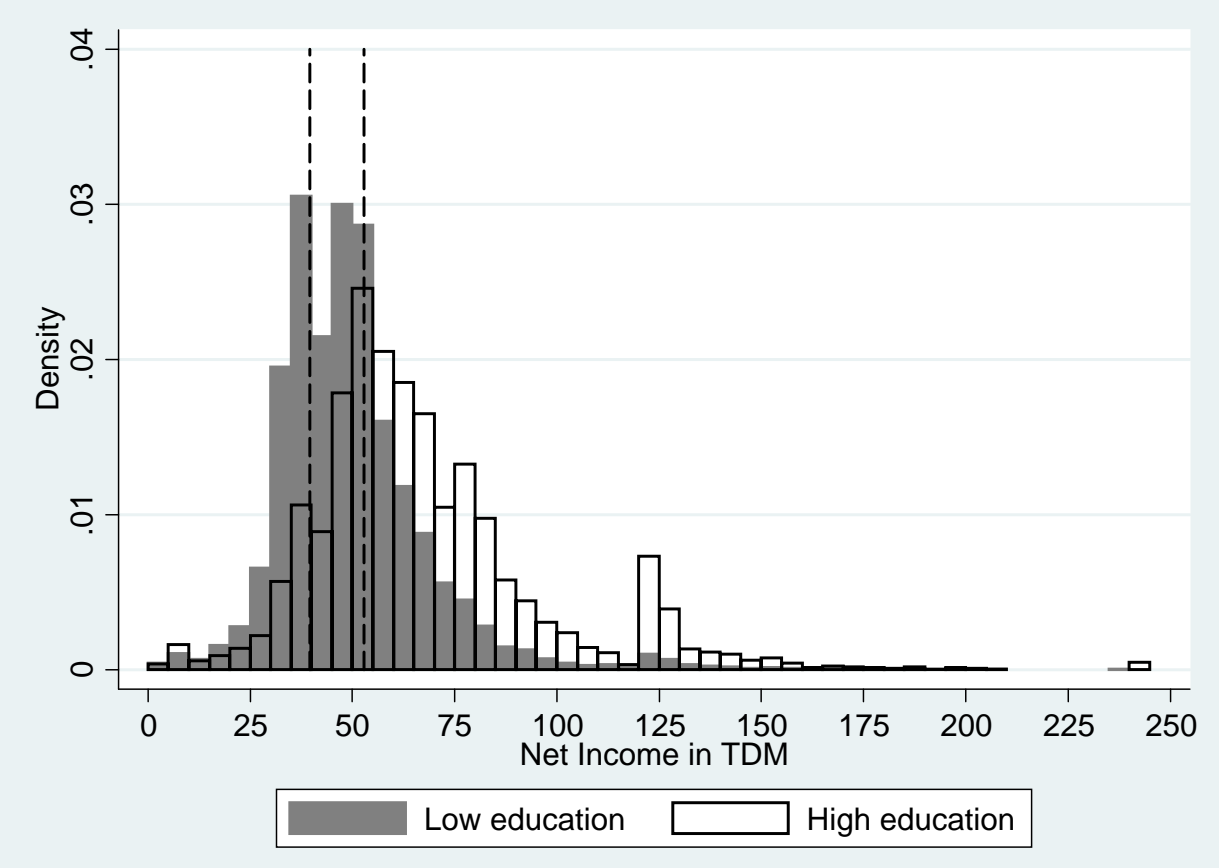

Notes: We report income in net amounts, because the Mikrozensus does not contain information on gross income. The dashed lines represent the thresholds of 39,600 and 52,800 DM, which is the approximate range that that captures the two-child families for which the reform decreased the financial incentives to have third child.

Source: Own calculations based on the Mikrozensus waves 1995, 1996, 1998, and 1999. 
Figure B.3.1 Income distribution of families with two children in treatment and control group (narrow definition) - SOEP

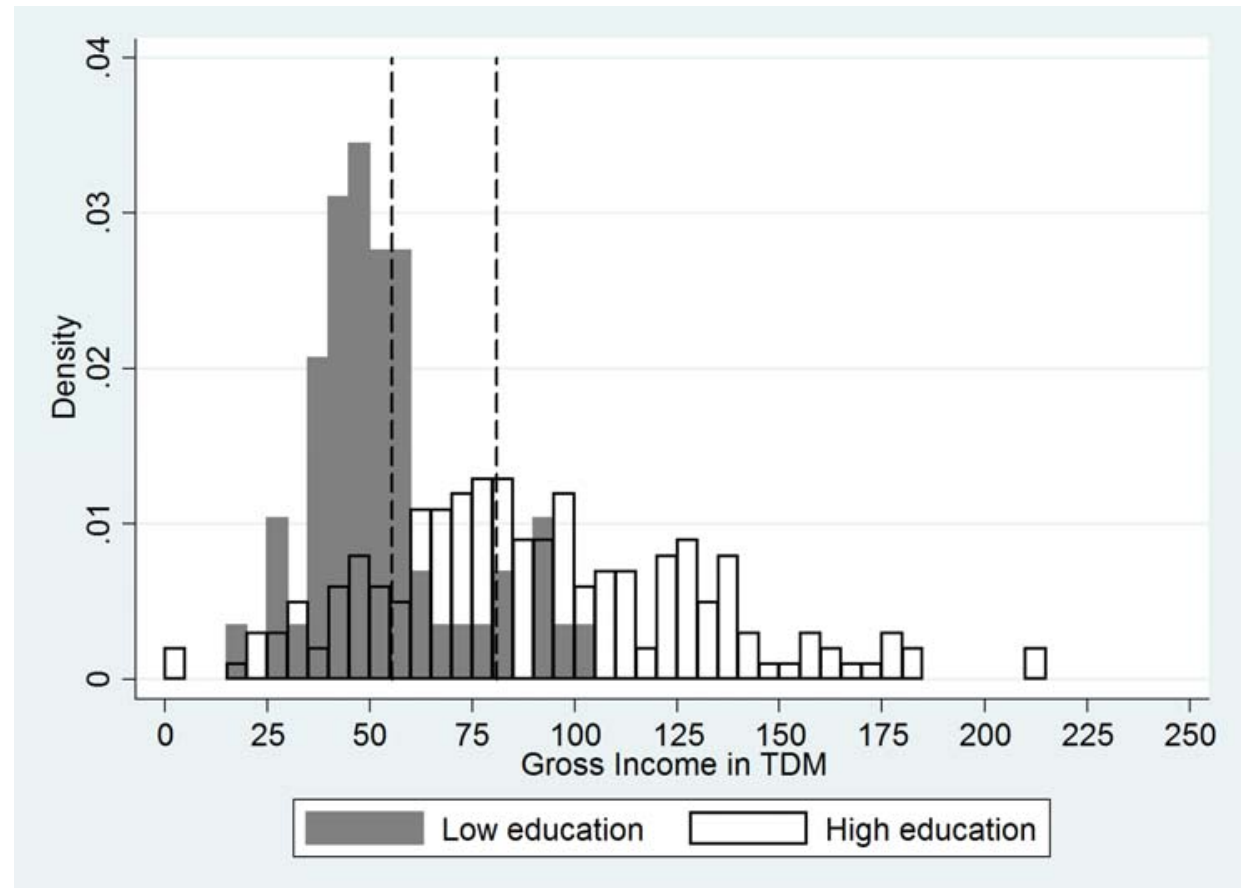

Figure B.3.2 Income distribution of families with two children in treatment and control group (broad definition) - SOEP

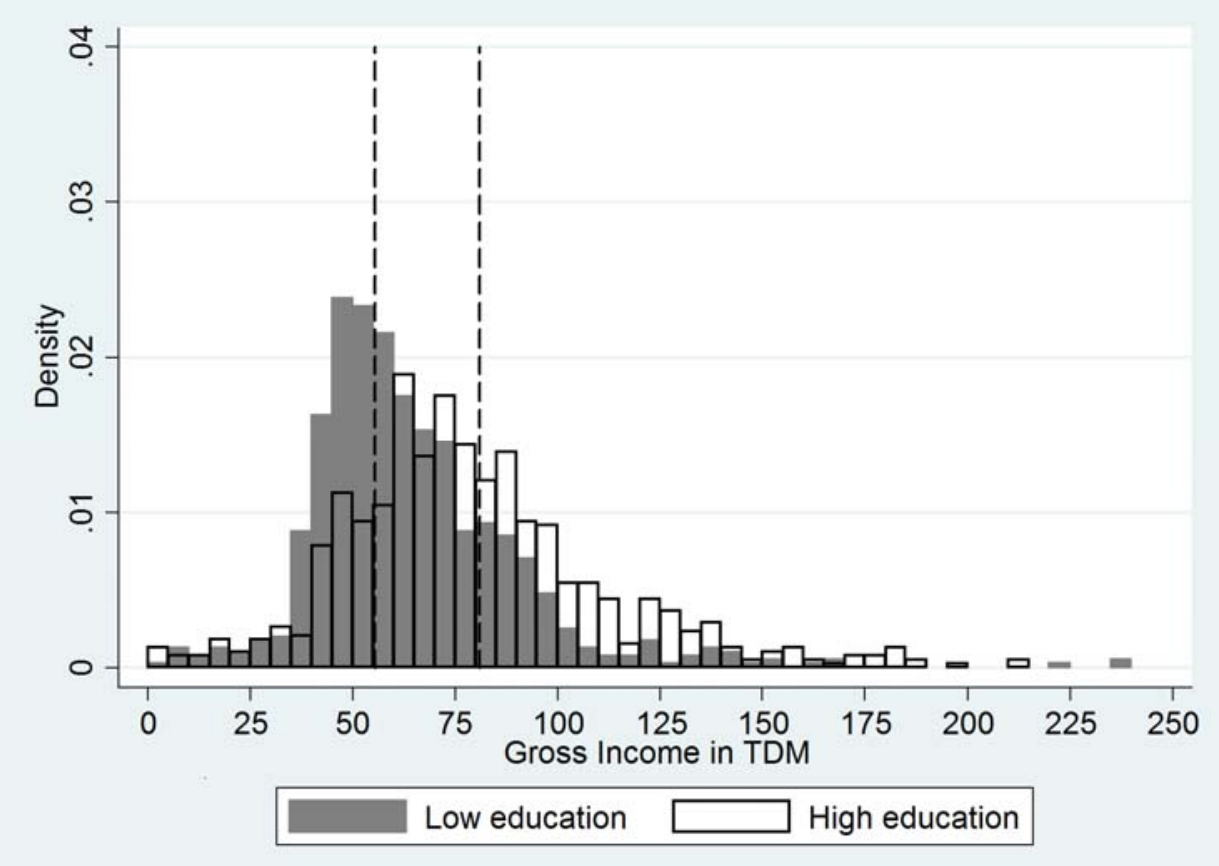

Notes: The dashed lines represent the thresholds of 55,400 and 81,000 DM, which is the range that captures the two-child families for which the reform decreased the financial incentives to have third child.

Source: Own calculations based on the SOEP waves 1992 to 1998. 
Figure B.4 Distribution of household net income and income-specific birthrates for third children

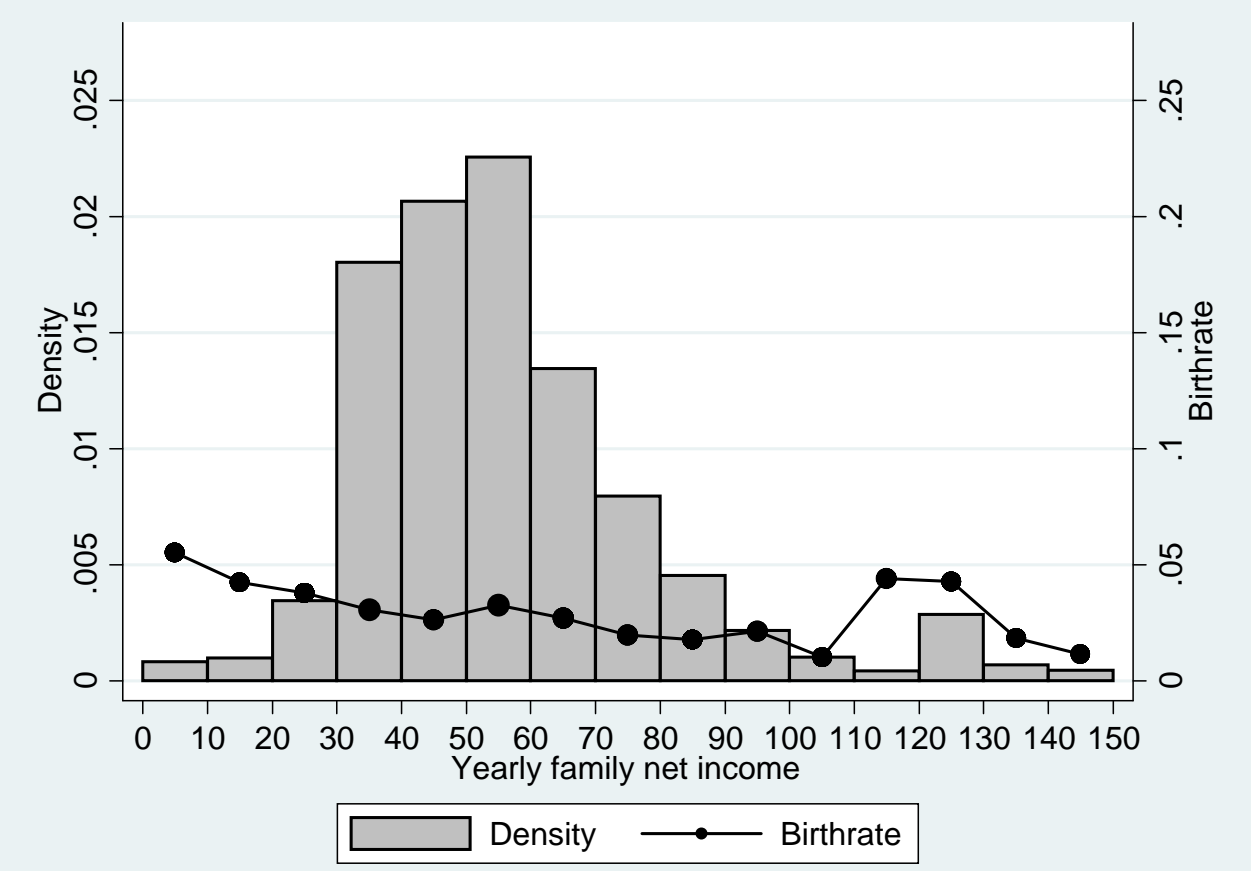

Source: Own calculations based on the Mikrozensus waves 1995, 1996, 1998, and 1999. 